\title{
Bio-Jet Fuel Conversion Technologies
}

\author{
Wei-Cheng Wang $^{1} *$ and Ling $\mathrm{Tao}^{2}$ \\ 1. Department of Aeronautics and Astronautics, National Cheng Kung University, No.1, University Road, \\ Tainan, Taiwan 70101 \\ 2. National Renewable Energy Laboratory, 15013 Denver West Parkway, Golden, CO 80401 \\ ${ }^{*}$ Corresponding author
}

\begin{abstract}
Biomass-derived jet (bio-jet) fuel has become a key element in the aviation industry's strategy to reduce operating costs and environmental impacts. Researchers from the oil-refining industry, the aviation industry, government, biofuel companies, agricultural organizations, and academia are working toward developing a commercially viable and sustainable process that produces a long-lasting renewable jet fuel with low production costs and low greenhouse emissions. This jet fuel, additionally, must meet ASTM International specifications and potentially be a $100 \%$ drop-in replacement for current petroleum jet fuel. In this study, the current technologies for producing renewable jet fuels, categorized by alcohols-to-jet, oil-to-jet, syngas-to-jet, and sugar-to-jet pathways are reviewed. The main challenges for each technology pathway, including conceptual process design, process economics and life-cycle assessment of greenhouse gas emissions are discussed. Although the feedstock price and availability and energy intensity of the process are significant barriers, biomass-derived jet fuel has the potential to replace a significant portion of conventional jet fuel required to meet commercial and military demand.
\end{abstract}

Key words: Bio-jet fuel; alcohol-to-jet; hydro-processed renewable jet; Fischer-Tropsch; catalytic upgrading sugars to hydrocarbons; direct sugar to hydrocarbon

Author contact information:

Wei-Cheng Wang

Tel: +886-6-2757575 ext. 63628

Email: wilsonwang@mail.ncku.edu.twmailto:wwang77777@gmail.com 


$\begin{array}{ll}\text { Acronyms } & \\ \text { ABE } & \text { acetone-butanol-ethanol } \\ \text { AFRL } & \text { U.S. Air Force Research Laboratory } \\ \text { APR } & \text { aqueous phase reforming } \\ \text { ASTM } & \text { ASTM International } \\ \text { ATJ } & \text { alcohol-to-jet } \\ \text { BIRD } & \text { Binational Industrial Research and Development } \\ \text { BTL } & \text { biomass-to-liquid } \\ \text { CH } & \text { catalytic hydrothermolysis } \\ \text { CLEEN } & \text { Continuous Lower Energy, Emissions and Noise } \\ \text { CO } & \text { carbon monoxide } \\ \text { CO } 2 & \text { carbon dioxide } \\ \text { CTL } & \text { coal-to-liquid } \\ \text { DARPA } & \text { Defense Advanced Research Projects Agency } \\ \text { DCN } & \text { Derived Cetane Number } \\ \text { DMF } & \text { 2,5-dimethylfuran } \\ \text { DOE } & \text { U.S. Department of Energy } \\ \text { DSH } & \text { Direct Sugar to Hydrocarbons } \\ \text { E. coli } & \text { Escherichia coli } \\ \text { FAA } & \text { Federal Aviation Administration } \\ \text { FFA } & \text { free fatty acid } \\ \text { F-T } & \text { Fischer-Tropsch } \\ \text { gCO } 2 \text { e } & \text { grams carbon dioxide equivalent } \\ \text { GGE } & \text { gallon of gasoline equivalent } \\ \text { GHG } & \text { greenhouse gas } \\ \text { GJ } & \text { gigajoules } \\ \text { GTJ } & \text { gas-to-jet } \\ \text { GTL } & \text { gas-to-liquid } \\ \text { H2 } & \text { hydrogen } \\ \text { HDCJ } & \text { hydrotreated depolymerized cellulosic jet } \\ \text { HEFA } & \text { hydroprocessed esters and fatty acids } \\ \text { HMF } & \text { 5-hydroxymethylfurfural } \\ \text { HRJ } & \text { hydroprocessed renewable jet } \\ \text { LCA } & \text { life-cycle assessment } \\ \text { LHV } & \text { lower heating value } \\ \text { MIL } & \text { military } \\ \text { MJ } & \text { megajoules } \\ \text { NAWCWD } & \text { Naval Air Warfare Center Weapons Division } \\ \text { NO } & \text { oxides of nitrogen } \\ \text { NETL } & \text { National Energy Technology Laboratory } \\ \text { NRC } & \text { National Research Council Canada } \\ \text { NREL } & \text { National Renewable Energy Laboratory } \\ \text { OTJ } & \text { oil-to-jet } \\ \text { READI } & \text { renewable, aromatic, and drop-in } \\ \text { RTP } & \text { rapid thermal processing } \\ \text { SPK } & \text { synthetic paraffinic kerosene } \\ \text { STJ } & \text { sugar-to-jet } \\ \text { TTW } & \text { tank-to-wake } \\ \text { WTT } & \text { well-to-tank } \\ \text { WTW } & \text { well-to-wake } \\ & \end{array}$




\section{Table of Contents}

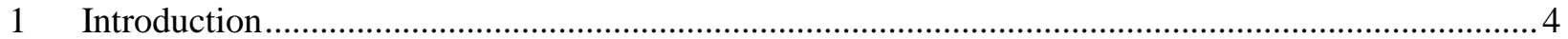

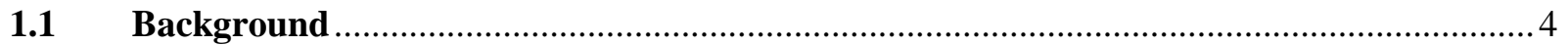

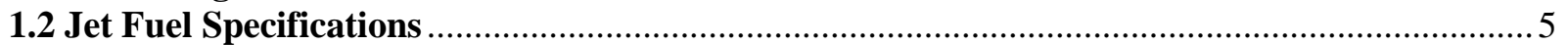

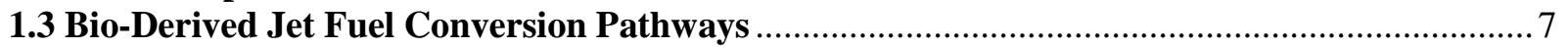

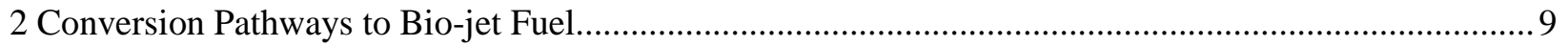

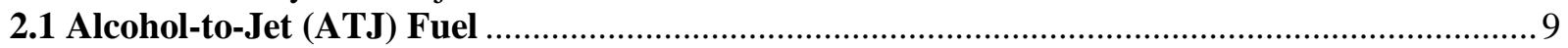

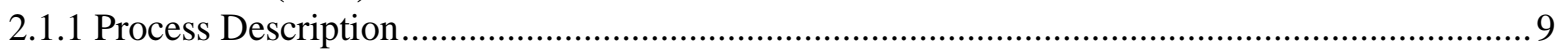

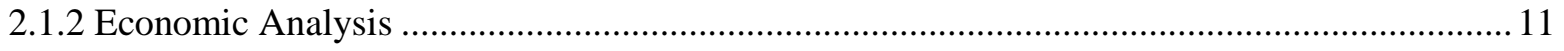

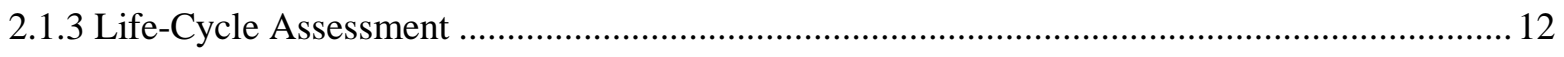

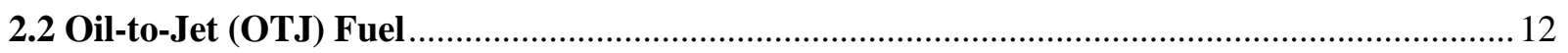

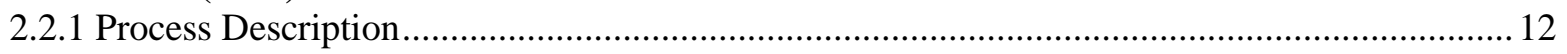

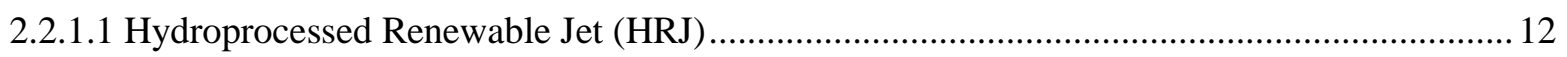

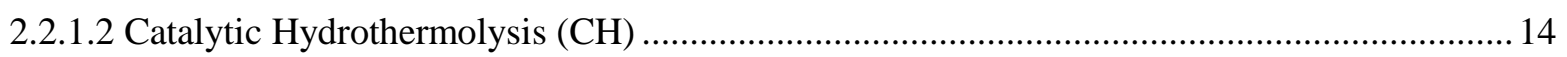

2.2.1.3 Hydro-treated Depolymerized Cellulosic Jet (fast pyrolysis with upgrading to jet fuel) ....... 15

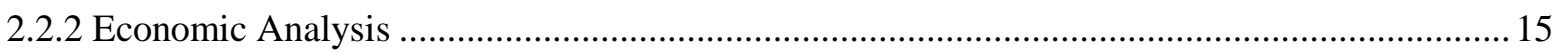

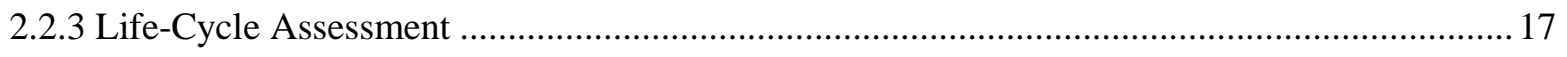

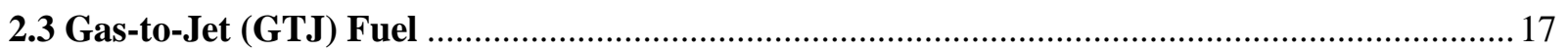

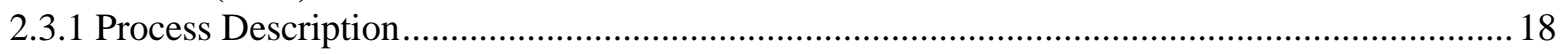

2.3.1.1 Fisher Tropsch Biomass to Liquid (FT-BTL) Process......................................................... 18

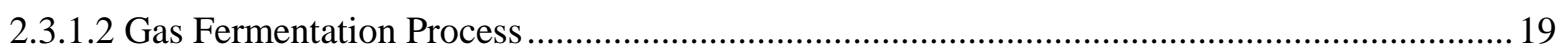

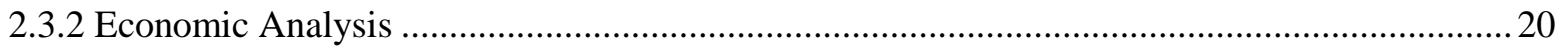

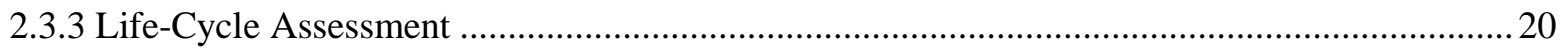

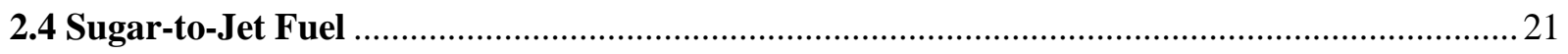

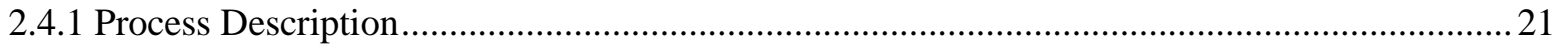

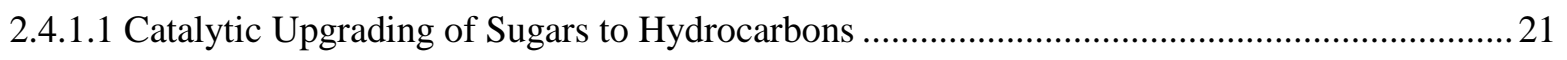

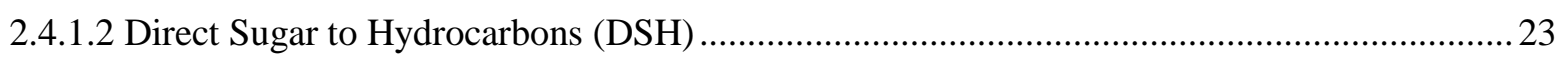

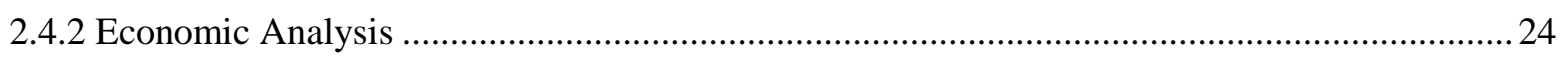

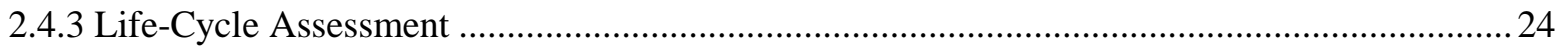

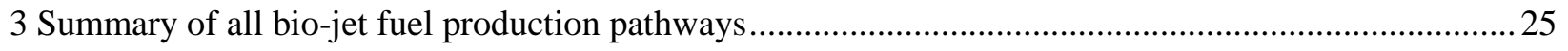

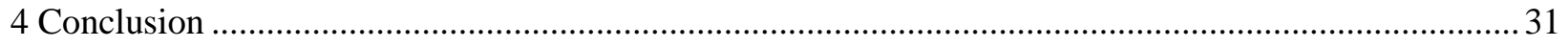

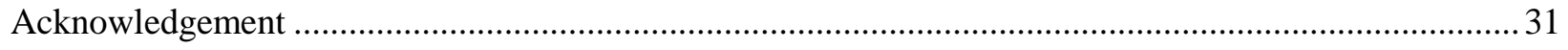

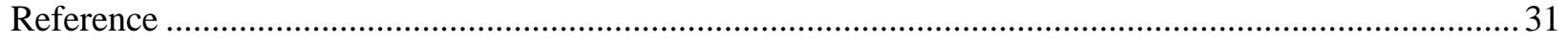




\section{Introduction}

\subsection{Background}

Fuel is one of the biggest operating costs for the aviation industry. Aviation fuel, a petroleum-based fuel used to power aircraft, has stricter quality requirements than fuels used in road transport. Jet fuel, a type of aviation fuel designed specifically to power the gas-turbine engines, will be the primary subject of this review. According to a report from the U.S. Department of Energy's (DOE's) Bioenergy Technologies Office [1], out of one barrel of crude oil, 4 gallons are used to produce jet fuel. The worldwide aviation industry consumes approximately 1.5 to 1.7 billion barrels ( 47.25 to 53.55 billion gallons) of conventional jet fuel per year $[2,3]$. The challenges of crude oil prices, national security, environmental impact, and sustainability make it difficult to have a long term plan and budget for operating expenses. Sustainable biofuels produced globally offer a solution to these issues. Biomass-derived jet fuels (bio-jet fuels) are a potential alternative to petroleum jet fuel.

Many process technologies that convert biomass-based materials into jet fuel substitutes are available. Some are available at commercial or pre-commercial scale, and others are still in the research and development stage. These technologies are varied and depend strongly on the type of feedstock. Oil-based feedstocks are converted into bio-jet fuels through hydro-processing technologies, including hydrotreating, deoxygenation, and isomerization/hydrocracking. Processes such as catalytic hydro-thermolysis $(\mathrm{CH})$ have also been developed to treat triglyceride-based oils. Solid-based feedstocks are converted into biomass derived intermediate through gasification, into alcohols through biochemical or thermochemical processes, into sugars through biochemical processes, and into bio-oils through pyrolysis processes. Syngas, alcohols, sugars, and bio-oils can be further upgraded to bio-jet fuel via a variety of synthesis, fermentative, or catalytic processes. So far, bio-jet fuels from Fischer-Tropsch (F-T) synthesis and oil hydro-processing technologies have been approved by ASTM International (ASTM) Method D7566 [4] for blending into jet at levels up to 50\%. Hydro-processing technologies using vegetable and waste oils represent the only conversion pathways ready for large-scale deployment [5]. Industries are currently working on developing optimal processes that utilize sustainable feedstocks and can be produced economically.

Production cost is a key parameter of the commercial feasibility of a bio-jet fuel. U.S. passenger and cargo airlines require more than 18 billion gallons of jet fuel annually. Therefore, every penny increase in the price of jet fuel results in an additional $\$ 180$ million in annual fuel costs for U.S. airlines [6]. The price of petroleum-derived jet fuel is directly correlated with the price of crude oil [7]. Changes in crude oil price make it difficult to plan and budget long-term operating expenses for jet fuel refining. In 2012, the annual fuel cost for all airlines was around $\$ 47$ billion [8]. It is predicted that by 2030, the bio-jet fuel production cost may drop to as low as $\$ 2.54 / \mathrm{gal}$ due to improved conversion technology [9], and $30 \%$ of annual airline fuel consumption can be replaced by bio-jet fuel [2]. Following the same pattern for bioethanol production [10], the variation in the bio-jet production cost would be highly dependent on the following parameters: (1) composition and cost of feedstock; (2) process design; (3) conversion efficiency or product yield; (4) valorization of co-products; and (5) energy conservation. Therefore, decreasing the production cost of bio-jet fuel depends on synergistic efforts in all areas, including improvements in the areas of feedstock productivity, extraction yield of oil or sugar yield from the crops, process energy conservation, and balance between jet fuel product and value-added co-products.

In addition, there is a growing awareness of important environmental issues, including improving air quality in and around airports and determining the aviation industry's contribution to greenhouse gas (GHG) emissions globally. It has been estimated that commercial aviation has contributed approximately $2 \%-6 \%$ to total global carbon emissions [11]. Jet fuels derived from renewable resources may offer the potential to reduce the GHG emissions from aviation. A life-cycle assessment (LCA) that considers emissions from the field where the feedstock is harvested to the wake behind the aircraft can provide the change in GHG emissions due to the use of alternative fuels [3], usually known as well-to-wake (WTW) analysis. The WTW analysis can be split into two parts: well-to-tank (WTT) and tank-to-wake (TTW) 
[12]. To compare the GHG emissions due to bio-jet fuels with that of conventional jet fuels, it is necessary to consider emissions from the whole production chain. In the WTT portion, feedstock production, land use change, and conversion processes contribute significantly to GHG emissions. In the TTW portion, emissions from burning jet fuels are considered [12]. The WTW GHG emissions from conventional jet fuel are reported to be 87.5 grams carbon dioxide equivalent per megajoule $\left(\mathrm{gCO}_{2} \mathrm{e} / \mathrm{MJ}\right)$ [13], including $14.3 \mathrm{gCO}_{2} \mathrm{e} / \mathrm{MJ}$ WTT GHG emissions and $73.2 \mathrm{gCO}_{2} \mathrm{e} / \mathrm{MJ}$ TTW GHG emissions [14]. When bio-jet fuel is used for aviation, the GHG emissions can be reduced to $1.5 \mathrm{gCO}_{2} \mathrm{e} / \mathrm{MJ}$ (open pond algal oil case), a 98\% reduction relative to conventional jet fuel [15]. Different conversion technologies may result in different amounts and types of GHG emissions due to the variety of feedstocks and reaction processes. Reviewing the GHG emissions data from the conversion pathways will help determine the optimal platforms for producing bio-jet fuel.

Groups such as aircraft manufacturers, airline companies, academic institutions, fuel refining companies, agricultural companies, farmers groups, and local/regional/national departments of agriculture, defense, transport, economic development, and enterprise are working together to develop commercially feasible bio-jet fuel [16]. The level of bio-jet fuel commercialization depends on feedstock availability, conversion technology development, reduction of GHG emissions, and policy. Conversion technologies for transportation biofuels such as ethanol [17] and biodiesel [18] have been reviewed and compared extensively. For future development and deployment of bio-jet fuel, it is important to review and understand the maturity and uncertainty of all pathways to assess impacts on commercialization.

\subsection{Jet Fuel Specifications}

In addition to define target compositions, jet fuel specifications and requirements are mostly defined in terms of required performance properties. The specifications required for jet fuels are (1) acceptable minimum energy density by mass, (2) maximum allowable freeze point temperature, (3) maximum allowable deposits in standard heating tests, (4) maximum allowable viscosity, (5) maximum allowable sulfur and aromatics content, (6) maximum allowable amount of wear in standardized test, (7) maximum acidity and mercaptan concentration, (8) minimum aromatics content, (9) minimum fuel electrical conductivity, and (10) minimum allowable flash point [19]. There are three standards for certifying aviation fuel : ASTM D1655 [20, 21], International Air Transport Association Guidance Material (Kerosene Type) [20, 21], and the United Kingdom Ministry of Defence, Defence Standard (Def Stan) 91-91 [22]. ASTM Specification D7566 (Standard Specification for Aviation Turbine Fuel Containing Synthesized Hydrocarbons), which targets alternative jet fuel, lists the fuel properties and criteria required to control the production and quality of a renewable fuel for aviation safety [23]. There might be other fuel standards, and Table 1 shows the specifications for two typical jet fuels for commercial and military aircraft. Jet fuel requires a high flash point due to the fire-hazard consideration [24]. Major fuel properties are similar across different standards, but there are some differences. For instance, D7566 is an expansion of D1655 to include fuel specifications required of the SPK blendstocks. In addition, jet fuel needs good cold flow properties, such as a lower freezing point, to ensure the fuel can flow at high altitude [25]. 
Table 1. Jet Fuel Specifications [19, 22-24, 26]

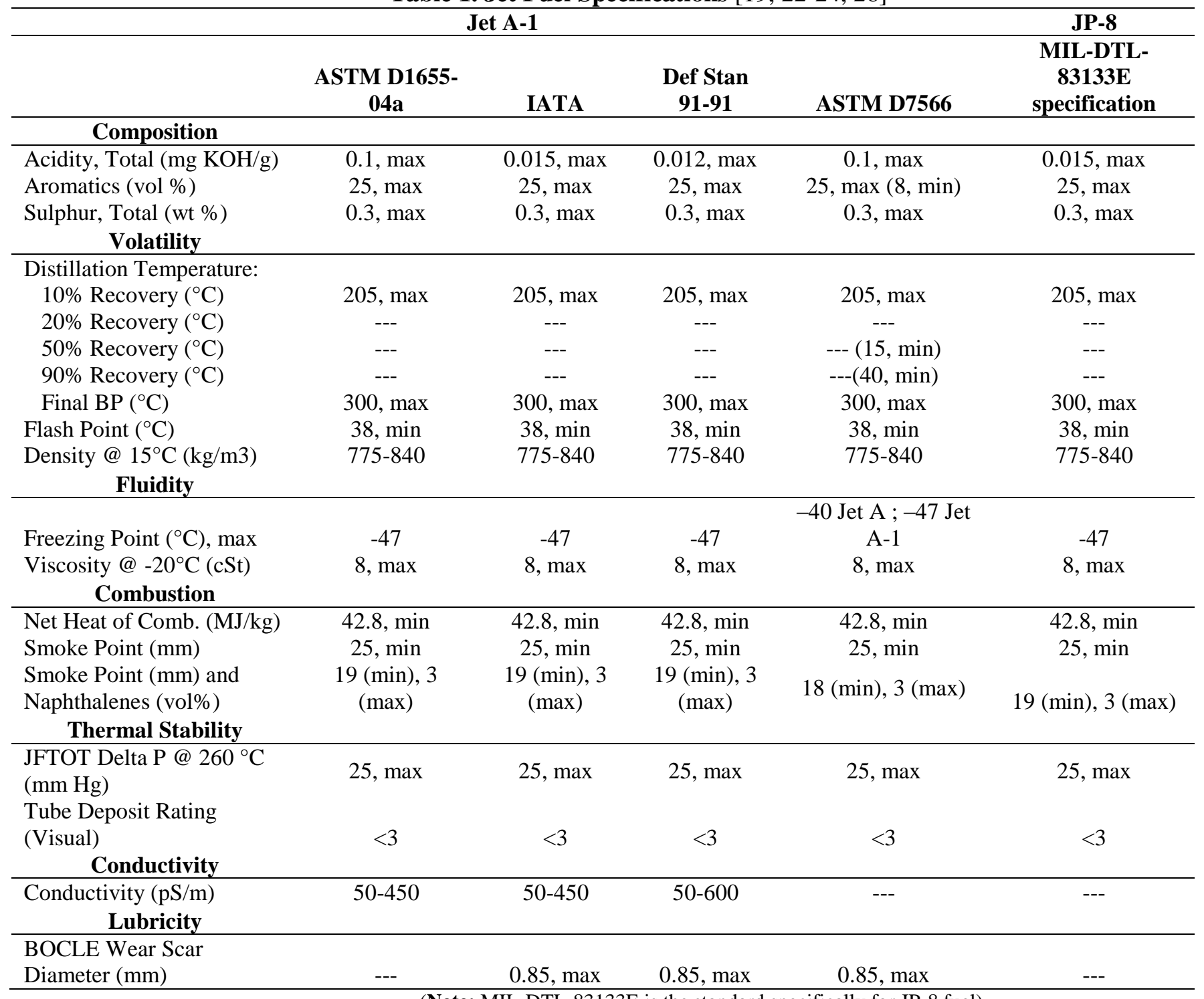

(Note: MIL-DTL-83133E is the standard specifically for JP-8 fuel) 


\subsection{Bio-Derived Jet Fuel Conversion Pathways}

Biomass-derived jet fuel can provide a near-term and even long-term solution to the airline industry and the military with a lower environmental impact than petroleum fuels. Many bio-jet fuel conversion technologies, whether in the research and development, demonstration, or commercial stages, are described in the literature. Jet fuel blended with up to 50\% bio-jet fuel from an F-T process was certified in August 2009 [12, 27-29]. Bio-jet fuels from hydro-processing technologies, such as hydro-treated esters and fatty acids (HEFA) or hydro-processed renewable jet (HRJ), were also studied extensively [3033]. Conversion of alcohol to jet fuel, called alcohol-to-jet (ATJ), has also been developed at commercial scale and was flight-tested by the U.S. Air Force in July 2012 [34-38]. Fuel produced by two recently proposed sugar-to-jet (STJ) fuel processes, fermentation of sugars to hydrocarbons [39] and catalytic conversion of sugars to fuels [40], have been developed in joint ventures by biofuel and oil companies [41-48]. Two recently proposed processes, $\mathrm{CH}$ and hydro-treated depolymerized cellulosic jet (HDCJ), also called pyrolysis, have not yet been approved by ASTM, but several companies and research institutes are working on this technology [49-52]. Currently bio-jet fuels from ATJ, HRJ, and F-T synthesis have been used for commercial and military flights, as shown in Table 2.

Some of the technologies that convert bio-based feedstocks to jet fuel have been reviewed in the literature in areas including feedstock availability, upgrading technology, process economics, lifecycle GHG analysis, and commercial progress [5, 11, 12, 21, 53-57]. Most literature has focused on approved technologies such as F-T synthesis and HRJ processes; few literature references are available for either ATJ or STJ processes because they are still in the development stage. To fully understand current biomass-to-jet fuel development, it is necessary to have an overview of all of the upgrading technologies, both approved and pending approval, from laboratory to commercial scale. In this review, the upgrading pathways are classified as one of four types, based on the feedstocks and conversion processes: (1) alcohol-to-jet (ATJ), (2) oil-to-jet (OTJ), (3) gas-to-jet (GTJ), and (4) sugar-to-jet (STJ) (shown in Table $3)$. Detailed information and literature data, such as potential feedstocks, process technologies, cost analysis comparisons, life-cycle assessment studies, and pre-commercial or commercial demonstrations for each pathway, are described in this report in the following sections.

Table 2a. Flight Tests with Bio-jet Fuels Through Different Conversion Pathways [58] by Commercial Airlines.

\begin{tabular}{|c|c|c|c|c|c|c|}
\hline $\begin{array}{l}\text { Commercial } \\
\text { Airline }\end{array}$ & Aircraft & Partners & Year & Feedstocks & $\begin{array}{c}\text { Bio-jet Fuel } \\
\text { Content }\end{array}$ & $\begin{array}{c}\text { Conversion } \\
\text { Pathway } \\
\end{array}$ \\
\hline Virgin Atlantic & B747-400 & Boeing, GE Aviation & 2008 & Coconut \& Babassu & $20 \%$ & Oil to Jet \\
\hline Air New Zealand & B747-400 & Boeing Ralls-Royce, UOP & 2008 & Jatropha & $50 \%$ & Oil to Jet \\
\hline $\begin{array}{l}\text { Continental } \\
\text { Airlines }\end{array}$ & B737-800 & $\begin{array}{c}\text { Boeing, GE Aviation, CFM, } \\
\text { Honeywell UOP }\end{array}$ & 2009 & $\begin{array}{l}2.5 \% \text { Algae \& } 47.5 \% \\
\text { Jatropha }\end{array}$ & $50 \%$ & Oil to Jet \\
\hline JAL & B747-400 & $\begin{array}{c}\text { Boeing, Pratt \& Whitney, } \\
\text { Honeywell UOP, Nikki Universal }\end{array}$ & 2009 & $\begin{array}{l}42 \% \text { Camelina, } 8 \% \\
\text { Jatropha/Algae }\end{array}$ & $50 \%$ & Oil to Jet \\
\hline KLM & B747-400 & GE, Honeywell UOP & 2009 & Camelina & $50 \%$ & Oil to Jet \\
\hline KLM & B737-800 & & 2011 & Waste cooking oil & $50 \%$ & Oil to Jet \\
\hline TAM Airlines & A-320 & Airbus, CFM & 2010 & Jatropha & $50 \%$ & Oil to Jet \\
\hline Jet Blue Airways & A-320 & Airbus, IAE, Honeywell UOP & 2010 & TBC & & Oil to Jet \\
\hline Boeing & B747-8F & & 2011 & Camelina & $15 \%$ & Oil to Jet \\
\hline Interjet & A-320 & $\begin{array}{l}\text { CFM, Safran, EADS, Airbus, } \\
\text { Honeywell UOP }\end{array}$ & 2011 & Jatropha, Halophyte & $30 \%$ & Oil to Jet \\
\hline Air France & A-321 & & 2011 & Waste cooking oil & $50 \%$ & Oil to Jet \\
\hline Honeywell & Gulfstream G450 & & 2011 & Camelina & $50 \%$ & Oil to Jet \\
\hline Finnair & A-319 & & 2011 & Waste cooking oil & $50 \%$ & Oil to Jet \\
\hline Air Mexico & B777-200 & & 2011 & Jatropha & & Oil to Jet \\
\hline $\begin{array}{l}\text { Thomson } \\
\text { Airways }\end{array}$ & B757-200 & SkyNRG & 2011 & Waste cooking oil & & Oil to Jet \\
\hline Porter Airlines & Bombardier Q400 & & 2012 & Camelina & & Oil to Jet \\
\hline Air China & B747-400 & Boeing, PetroChina & 2012 & Jatropha & $50 \%$ & Oil to Jet \\
\hline NRC Canada & Falcon 20, T-33 & $\begin{array}{l}\text { Aemetis, AFRL, Rolls-Royce, } \\
\text { FAA-CLEEN, Agrisoma } \\
\text { Biosciences, Applied Research } \\
\text { Assoc., Chevron Lummus Global }\end{array}$ & 2012 & Carinata & $100 \%$ & Oil to Jet $(\mathrm{CH})$ \\
\hline
\end{tabular}




\begin{tabular}{|c|c|c|c|c|c|c|}
\hline Lufthansa & A-321 & Neste Oil & 2011 & $\begin{array}{c}\text { Jatropha, camelina \& } \\
\text { animal fats }\end{array}$ & $50 \%$ & Oil to Jet \\
\hline Azul Airlines & E195 Jet & Amyris, Embraer, GE & 2012 & Sugarcane & & Sugar to Jet \\
\hline $\begin{array}{l}\text { Continental } \\
\text { Airlines }\end{array}$ & B737-800 & Solazyme, United Airlines & 2011 & Algae & & Alcohol to Jet \\
\hline Alaska Airlines & $\begin{array}{c}\text { B737, Bombardier } \\
\text { Q400 }\end{array}$ & Dynamic Fuels, Horizon Air & 2011 & $\begin{array}{c}\text { Algae \& waste cooking } \\
\text { oil }\end{array}$ & $20 \%$ & Oil to Jet \\
\hline Virgin Atlantic & & Lanza Tech, Swedish Biofuels & 2011 & Industrial waste gas & & $\begin{array}{l}\text { Gas to Jet } \\
\text { (gas } \\
\text { fermentation) }\end{array}$ \\
\hline Etihad Airways & B777-300ER & & 2012 & vegetable oil & & Oil to Jet \\
\hline British Airways & TBD & Solena & TBD & Factory waste & TBD & $\begin{array}{l}\text { Gas to Jet (F- } \\
\text { T) }\end{array}$ \\
\hline $\begin{array}{c}\text { Paramus Flying } \\
\text { Club }\end{array}$ & Cessna 182 & & 2013 & Waste cooking oil & $50 \%$ & Oil to Jet \\
\hline
\end{tabular}

Table 2b. Flight Tests with Bio-jet Fuels Through Different Conversion Pathways [58] by Military Aircrafts Types.

\begin{tabular}{|c|c|c|c|c|c|c|}
\hline Military Aircraft & Aircraft & Partners & Year & Feedstocks & $\begin{array}{c}\text { Bio-jet Fuel } \\
\text { Content }\end{array}$ & $\begin{array}{c}\text { Conversion } \\
\text { Pathway }\end{array}$ \\
\hline U.S. Navy & F/A-18 & Honeywell UOP & 2010 & Camelina & $50 \%$ & Oil to Jet \\
\hline U.S. Air Force & A-10C & Honeywell UOP & 2010 & $\begin{array}{l}\text { Camelina, waste } \\
\text { cooking oil }\end{array}$ & $50 \%$ & Oil to Jet \\
\hline U.S. Air Force & F-22 & Honeywell UOP & 2011 & Camelina & $50 \%$ & Oil to Jet \\
\hline U.S. Navy & $\begin{array}{l}\text { MH60S Seahawk } \\
\text { Helicopter }\end{array}$ & & 2010 & Camelina & $50 \%$ & Oil to Jet \\
\hline U.S. Navy & $\begin{array}{c}\text { MH60S Seahawk } \\
\text { Helicopter }\end{array}$ & Solazyme & 2011 & Algae & $50 \%$ & Oil to Jet \\
\hline U.S. Navy & $\mathrm{T}-45$ & & 2011 & Camelina & $50 \%$ & Oil to Jet \\
\hline U.S. Navy & AV-8D & & 2011 & Camelina & & Oil to Jet \\
\hline $\begin{array}{l}\text { Netherland Air } \\
\text { Force }\end{array}$ & $\begin{array}{c}\text { AH-64D Apache } \\
\text { Helicopter }\end{array}$ & Honeywell UOP & 2010 & Waste cooking oil & $50 \%$ & Oil to Jet \\
\hline U.S. Air Force & A-10C & Gevo & 2012 & $\begin{array}{c}\text { cellulose-derived } \\
\text { alcohol }\end{array}$ & & Alcohol to Jet \\
\hline U.S. Air Force & B-52 & Syntroleum & 2006 & natural gas & $50 \%$ & Gas to Jet (F-T) \\
\hline U.S. Air Force & TBD & Swedish Biofuels & TBD & Biomass-derived sugar & $100 \%$ & Alcohol to Jet \\
\hline NASA & DC-8 & & 2011 & Chicken and beef tallow & & Oil to Jet \\
\hline Dutch Military & $\begin{array}{l}\text { Ah-64 Apache } \\
\text { helicopter }\end{array}$ & & 2010 & Waste cooking oil & & Oil to Jet \\
\hline EADs & Diamond D42 & & 2010 & Algae & & Oil to Jet \\
\hline
\end{tabular}

Table 3. Summary of Jet Fuel Production Pathways Reviewed in This Work

\begin{tabular}{|c|c|c|c|c|}
\hline Category & Pathways & Companies & $\begin{array}{c}\text { U.S. or International } \\
\text { Agencies }\end{array}$ & Airline Companies/Manufacturers \\
\hline \multirow{2}{*}{$\begin{array}{l}\text { Alcohol } \\
\text { to Jet }\end{array}$} & Ethanol to Jet & $\begin{array}{l}\text { Terrabon/MixAlco; Lanza } \\
\text { Tech/Swedish Biofuels ; Coskata }\end{array}$ & $\begin{array}{l}\text { Defense Advanced Research } \\
\text { Projects Agency, FAA }\end{array}$ & Boeing, Virgin Atlantic \\
\hline & Butanol to Jet & $\begin{array}{l}\text { Gevo; Byogy; Albemarle/Colbalt; } \\
\text { Solazyme }\end{array}$ & $\begin{array}{l}\text { Navy/NAWCWD, AFRL, DLA, } \\
\text { USAF }\end{array}$ & Continental Airlines ; United Airlines \\
\hline \multirow[t]{3}{*}{$\begin{array}{l}\text { Oil-to- } \\
\text { Jet }\end{array}$} & $\begin{array}{l}\text { Hydro-processed } \\
\text { Renewable Jet (HRJ) }\end{array}$ & $\begin{array}{l}\text { UOP; SG Biofuels; AltAir Fuels; } \\
\text { Agrisoma Biosciences; Neste Oil; } \\
\text { PetroChina; Sapphire Energy, } \\
\text { Syntroleum/Tyson Food; PEMEX ; } \\
\text { ASA }\end{array}$ & $\begin{array}{l}\text { U.S. Navy, USAF, Netherland } \\
\text { Air Force, NASA, Dutch } \\
\text { Military, EADs }\end{array}$ & $\begin{array}{l}\text { Boeing, Lufthansa, Virgin Atlantic, Virgin } \\
\text { Blue, GE Aviation, Air New Zealand, } \\
\text { Rolls-Royce, Continental, CFM, JAL, } \\
\text { Airbus, KLM, Interjet, Pratt \& Whitney, Air } \\
\text { China, TAM Airlines, Jet Blue Airways, } \\
\text { IAE, United Airlines, Air France, Finnair, } \\
\text { Air Mexico, Thomson Airways, Porter } \\
\text { Airlines, Alaska Airlines, Horizon Air, } \\
\text { Etihad Airways, Romanian Air, Bombardier }\end{array}$ \\
\hline & $\begin{array}{l}\text { Catalytic Hydro- } \\
\text { thermolysis }(\mathrm{CH})\end{array}$ & $\begin{array}{l}\text { Applied Research Assoc., } \\
\text { Aemetis/Chevron Lummus Global }\end{array}$ & $\begin{array}{l}\text { FAA CLEEN, NRC Canada, } \\
\text { AFRL }\end{array}$ & Rolls-Royce, Pratt \& Whitney \\
\hline & $\begin{array}{l}\text { Hydro-treated } \\
\text { Depolymerized } \\
\text { Cellulosic Jet (Pyrolysis) }\end{array}$ & $\begin{array}{l}\text { Kior/Hunt Refining/Petrotech, } \\
\text { Envergent, GTI, Dynamotive }\end{array}$ & FAA & N/A \\
\hline
\end{tabular}




\begin{tabular}{|c|c|c|c|c|}
\hline & (HDCJ) & & & \\
\hline \multirow{2}{*}{$\begin{array}{c}\text { Gas to } \\
\text { Jet }\end{array}$} & $\begin{array}{l}\text { Fischer-Tropsch } \\
\text { Synthesis }\end{array}$ & $\begin{array}{l}\text { Syntroleum; SynFuels; Rentech; } \\
\text { Shell; Solena }\end{array}$ & $\begin{array}{l}\text { U.S. DOE, U.S. DOD, USAF, } \\
\text { Ontario government }\end{array}$ & $\begin{array}{l}\text { Qatar Airways, United Airlines, Airbus, } \\
\text { British Airways }\end{array}$ \\
\hline & Gas Fermentation & $\begin{array}{l}\text { Coskata; IneosBio/Lanza Tech; } \\
\text { Swedish Biofuels }\end{array}$ & N/A & Virgin Atlantic \\
\hline \multirow{2}{*}{$\begin{array}{c}\text { Sugar to } \\
\text { Jet }\end{array}$} & $\begin{array}{l}\text { Catalytic Upgrading of } \\
\text { Sugar to Jet }\end{array}$ & Virent/Shell, Virdia & AFRL, U.S. DOE & N/A \\
\hline & $\begin{array}{l}\text { Direct Sugar to } \\
\text { Hydrocarbons }\end{array}$ & Amyris/Total, Solazyme, LS9 & Navy, FAA & $\begin{array}{l}\text { Boeing; Embraer; Azul Airlines; GE; Trip } \\
\text { Airlines }\end{array}$ \\
\hline
\end{tabular}

\section{Conversion Pathways to Bio-jet Fuel}

\subsection{Alcohol-to-Jet (ATJ) Fuel}

ATJ fuel, also called alcohol oligomerization, is fuel converted from alcohols, such as methanol, ethanol, butanol, and long-chain fatty alcohols. The maximum use of ethanol is $10-15 \%$ for the majority of gasoline-powered vehicles on the road today, which creates a blend wall that makes it difficult to achieve further market penetration of ethanol as a blend stock for gasoline. Therefore, upgrading ethanol to jet fuel blend stock presents a potential pathway for developing drop-in or fungible fuels for the jet fuel market. In this review, ethanol and butanol are the two primary alcohols discussed for jet fuel conversion.

\subsubsection{Process Description}

To make drop-in alternative jet fuel from alcohols, the differences in the physical and chemical properties between alcohols and conventional jet fuel have to be minimized. In the United States, anhydrous ethanol, at $99.5 \%-99.9 \%$ purity, is required to blend with gasoline to avoid separation [59]. However, for upgrading to jet fuel products, the necessity of high-purity ethanol is still uncertain. A typical three-step ATJ process that converts alcohols to jet fuel has been demonstrated [35]. The process includes alcohol dehydration, oligomerization, and hydrogenation. The overall process diagram for ethanol to jet fuel is shown in Figure 1. The advantage is that all of these process steps have been demonstrated on a commercially relevant scale and the risk of scale-up is expected to be reduced. However, the development and demonstration of the integrated process on biomass derived intermediates is necessary. [35].

Catalysts for upgrading alcohols to hydrocarbons are important. Studies on dehydration catalysis started with alumina and transition metal oxides and moved to silicoaluminophosphates (SAPO), H-ZSM-5 zeolite catalyst, and heteropolyacid catalysts [60]. The most promising case was found to be the $0.5 \% \mathrm{La}-$ $2 \%$ P H-ZSM-5 catalyst. Approximately $100 \%$ conversion and $99.9 \%$ ethylene selectivity are approached at $250^{\circ} \mathrm{C}$ and $2 \mathrm{~h}^{-1}$ weight hourly space velocity [61,62]. The dehydrated ethylene can be turned into linear $\alpha$-olefins via a catalytic oligomerization process [63]. Current commercial processes for making $\alpha$ olefins are focused on both homogeneous and heterogeneous catalysts [35]. Catalysts such as a Ziegler Natta-type catalyst [64], chromium diphosphine catalyst [65], and zeolites [35] have been studied extensively. With a temperature of $90^{\circ} \mathrm{C}-110^{\circ} \mathrm{C}$ and a pressure of 89 bar over a Ziegler Natta-type catalyst, $96 \%-97 \%$ yield of linear $\alpha$-olefins was produced with a carbon range of $\mathrm{C}_{4}-\mathrm{C}_{20}$ [64]. In industrial oligomerization processes, broader carbon number distributions are produced, such as 5\% $\mathrm{C}_{4}$; $50 \% \mathrm{C}_{6}-\mathrm{C}_{10} ; 30 \% \mathrm{C}_{12}$ and $\mathrm{C}_{14} ; 12 \% \mathrm{C}_{16}$ and $\mathrm{C}_{18}$; and $3 \% \mathrm{C}_{20}$ and $\mathrm{C}_{20+}$ [63], at $200{ }^{\circ} \mathrm{C}$ and 250 bar. The resulting olefins are distilled to diesel- and jet-range fuels and light olefins [66]. Light olefins $\left(\mathrm{C}_{4}-\mathrm{C}_{8}\right)$ separated by distillation are recycled back to the oligomerization step, shown in Figure 1a. Jet fuel range products $\left(\mathrm{C}_{9}-\mathrm{C}_{16}\right)$ can be subjected to hydrogenation, which operates at temperatures of $370^{\circ} \mathrm{C}$ and WHSV of $3 \mathrm{~h}^{-1}$ with feeding hydrogen over $5 \%$ by weight of palladium or platinum on activated carbon catalyst [67] The $\mathrm{C}_{9}-\mathrm{C}_{16}$ alkanes produced from the hydrogenation step are suitable for renewable jet fuels.

$\mathrm{N}$-butanol can be dehydrated to 1-butene at $380^{\circ} \mathrm{C}$ and 2.1 bar over the $\gamma$-alumina catalyst [68]. The highest yield of biobutenes is $98 \%$, with $95 \%$ selectivity of 1-butene [68]. The rest of the product is 2butene isomerized from 1-butene. The 1-butene is subjected to the oligomerization process to produce olefins ranging from $\mathrm{C}_{8}$ to $\mathrm{C}_{32}$ with the conversion of $97 \%$ [69]. The product distributions of the mixed olefins are $26.46 \% \mathrm{C}_{8}, 25.48 \% \mathrm{C}_{12}, 17.64 \% \mathrm{C}_{16}, 11.76 \% \mathrm{C}_{20}, 7.84 \% \mathrm{C}_{24}, 4.9 \% \mathrm{C}_{28}$ and $3.92 \% \mathrm{C}_{32}$ [38]. 
The reaction is operated at ambient temperature with stirring for 16 hours over the Group 4 transitionmetal catalysts in the presence of methylaluminoxane $\left(\mathrm{Cp}_{2} \mathrm{ZrCl}_{2} / \mathrm{MAO}\right)$ [70]. The 2-butene, containing cis- and trans-2-butenes, are considered as unreacted olefins and separated by temperature controlled distillation[71]. The $\mathrm{C}_{8}$ olefin, 2-ethyl-1-hexene, is distillated and sent to the dimerization reactor [69, 72]. The dimerization is operated at $116^{\circ} \mathrm{C}$ for 2 hours over Nafion catalyst. The $\mathrm{C} 8$ olefin is $100 \%$ converted, yielding to $90 \%$ of $\mathrm{C}_{16} \mathrm{H}_{32}$ [72]. The products from 1-butene oligomerization, ranging from $\mathrm{C}_{12}$ to $\mathrm{C}_{32}$, together with $\mathrm{C}_{16}$ olefins produced from dimerization, are sent to hydrogenation process [72] over 0.08 wt\% PtO2 catalyst. The resulting C12-C16 paraffins can be blended with jet fuel and the C20-C32 alkanes are separated and sold as lubricants [69]. In addition, n-butanol from ABE fermentation can be dehydrogenated over a $\mathrm{Pd} / \mathrm{C}-\mathrm{K}_{3} \mathrm{PO}_{4}$ catalyst, producing $\mathrm{C}_{5}-\mathrm{C}_{11}$ ketones [73]. These ketones can be deoxygenated to produce normal paraffins, similar to the components of jet, gasoline, and diesel fuels.

Iso-butanol produced from a process such as E. coli fermentation is dehydrated to a mixture of isobutene, n-butene (1-butene), and 2-butene (cis-2-butene and trans-2-butene) [74]. Acidic catalyst such as ZSM-5 zeolites, Y-type zeolites, and Amberlyst acidic resins can be used to catalyze a dehydration reaction, and different catalysts affect the selectivity of isobutene and the overal ${ }^{1} 1$ linear butenes[74]. With the overall isobutanol dehydration yield of $99.1 \%$, the selectivity is reported to be $95.1 \%$ isobutene, $1.6 \% 1$-butene, $0.5 \%$ trans-2-butene, and $1.9 \%$ cis-2-butene at $325^{\circ} \mathrm{C}$ using ZSM-5 catalyst at $2 \mathrm{~h}^{-1}$ WHSV [74]. In addition, Armstrong reports that isobutanol can be converted into isobutylene through the dehydration process operated at $310^{\circ} \mathrm{C}$ over $\gamma$-Alumina catalyst, resulting in $98 \%$ isobutanol conversion and $92 \mathrm{~mole} \%$ isobutylene selectivity [75]. The isobutene can be converted to oligomers, trimmers, and tetramers at $100^{\circ} \mathrm{C}$ using an Amberlyst-35 catalyst at a WHSV of $2 \mathrm{~h}^{-1}$, producing $20 \%, 70 \%$, and $10 \%$ for $\mathrm{C}_{8}, \mathrm{C}_{12}$, and $\mathrm{C}_{16}$ olefins, respectively $[66,67]$. The 1-butene is converted into $25 \%, 24 \%, 17 \%$, and $25 \%$ to $\mathrm{C}_{8}, \mathrm{C}_{12}$, $\mathrm{C}_{16}$, and $\mathrm{C}_{20}$ olefins, respectively, resulting in an overall 1-butene yield of $96 \%$ with $4 \%$ unreacted. To increase the jet and diesel yields, the $\mathrm{C}_{8}$ olefins can be distilled and sent to one additional dimerization process, operating at $116^{\circ} \mathrm{C}$ over a Nafion catalyst [72]. Alternatively, $\mathrm{C}_{8}$ olefins can be either converted into $\mathrm{C}_{16} \mathrm{H}_{32}$ through dimerization or reacted with butenes to produce $\mathrm{C}_{12}$ olefins, leading to the increase of $\mathrm{C}_{12}$ and $\mathrm{C}_{16}$ for the jet-range chemicals [66].

Another source for producing 1-butene reported by researchers at the University of Wisconsin-Madison is $\gamma$-valerolactone [76]. The $\gamma$-valerolactone produced from biomass-derived carbohydrates is converted into $96 \%$ butene and $\mathrm{CO}_{2}$ through the decarboxylation process over a silica/alumina catalyst at a pressure of 36 bar and temperature of $375^{\circ} \mathrm{C}$. The resulting butene is subsequently oligomerized over an Amberlyst- 70 catalyst at $170^{\circ} \mathrm{C}$ and 17 bar, resulting in $99 \%$ conversion of butene and $71 \%$ yield of $\mathrm{C}_{8}-$ $\mathrm{C}_{16}$ alkenes, which can be targeted for jet fuel application.

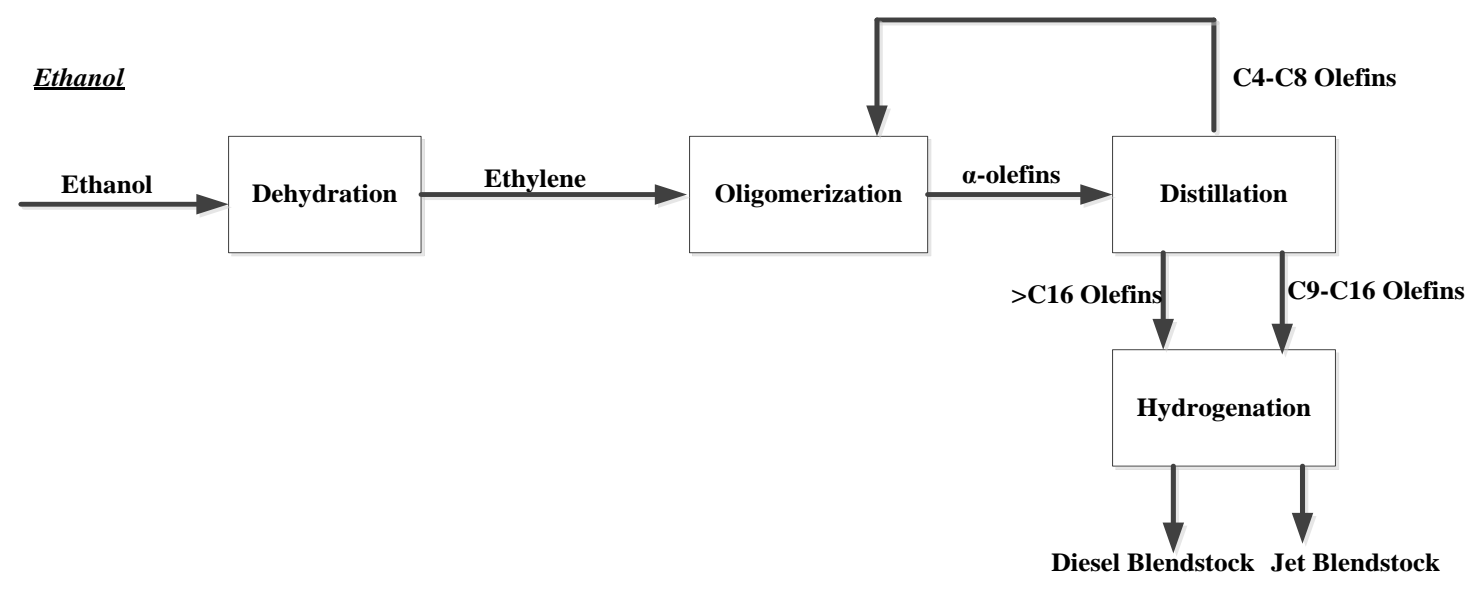

${ }^{1}$ Unless specified, all selectivities are mass $\%$. 
(1a)

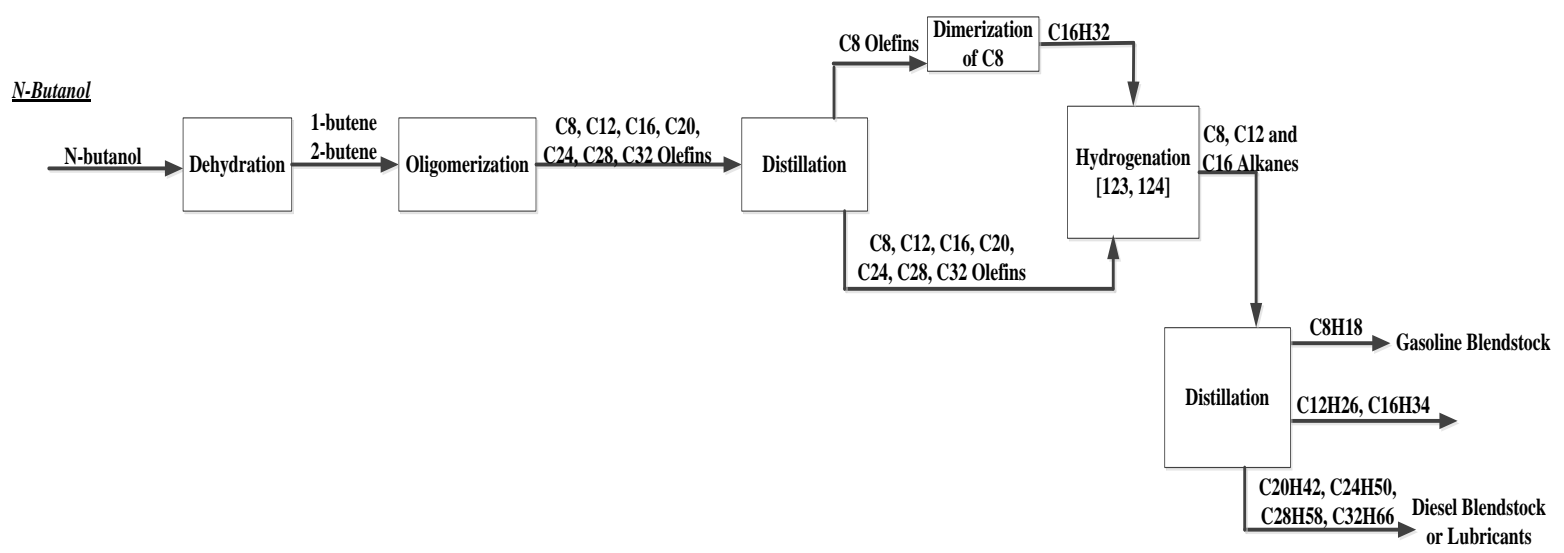

(1b)

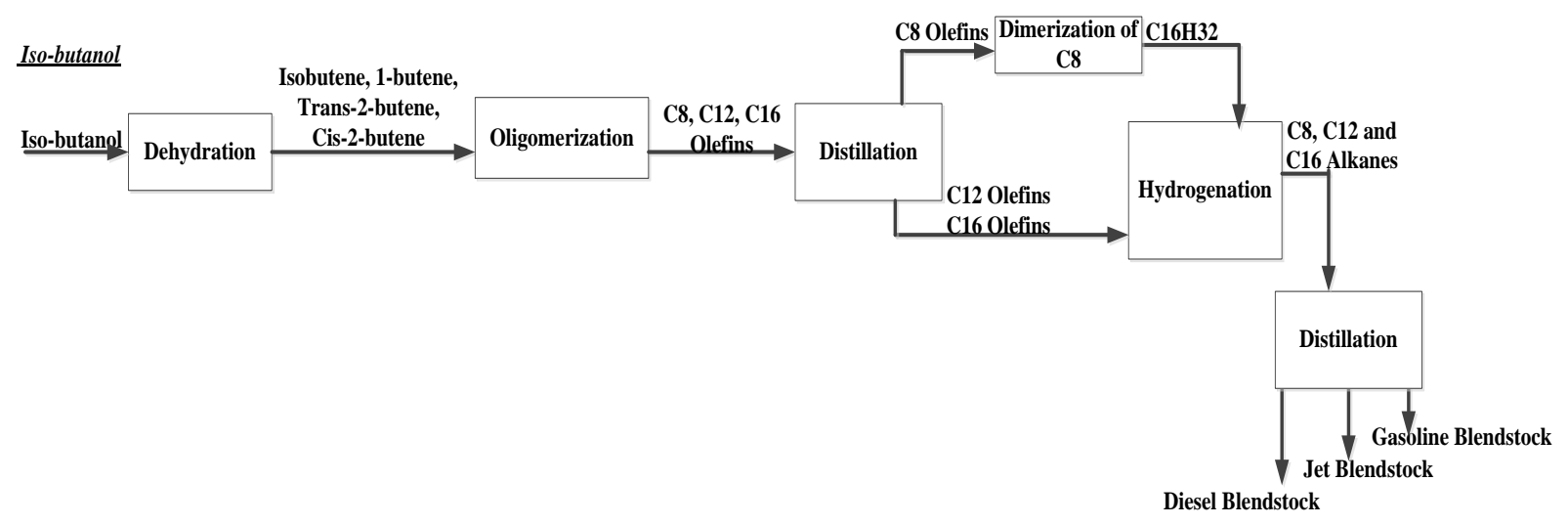

(1c)

Fig. 1. Alcohol to jet processes: (1a) ethanol to jet; (1b) n-butanol to jet; (1c) iso-butanol to jet $[35,38,60-63,65-69,71,72,74,77-81]$.

\subsubsection{Economic Analysis}

To evaluate the production cost for the bio-jet fuel derived from alcohols, the cost of making alcohols, such as ethanol and butanol (n-butanol and iso-butanol) needs to be determined. The techno-economic analysis of both biochemical and thermochemical processes $[82,83]$ for ethanol production(from starch or cellulosic feedstocks) has been studied extensively [10, 82-90]. Most reports calculate a minimum selling price of the fuel based on a number of economic assumptions. The minimum ethanol selling price for the biochemical conversion of lignocellulosic biomass was recently reported to be $\$ 2.15 / \mathrm{gal}$ or $\$ 3.27 / \mathrm{gal}$ of gasoline equivalent (GGE) in 2007 US dollars (\$2.76/gal or \$4.18/GGE in 2011 US dollars) [83]. The minimum ethanol selling price for the thermochemical route was reported to be $\$ 2.05 /$ gal or $\$ 3.11 / \mathrm{GGE}$ in 2007 US dollars ( $\$ 2.5 /$ gal or $\$ 3.8 /$ GGE on 2011 US dollars) [85].

The selling price of butanol from ABE fermentation is projected to be $\$ 0.34 / \mathrm{kg}$ ( $\$ 1.04 / \mathrm{gal})$ based on the corn feedstock cost of $\$ 79.23 /$ ton [91]. For cellulosic biomass, the price becomes $\$ 3.7 /$ gal or $\$ 4.1 / \mathrm{GGE}$ (2011 US dollars) [92]. According to the current market demand and the fluctuation of agricultural prices, cheaper feedstocks such as agricultural waste or algal biomass [93] are desired due to their renewability and non-competition with food. The substrate cost [91], credit for by-products [94], solvent recovery technology [91], and product molar ratio [95] are important factors for economic evaluation of butanol production.

To evaluate the overall ATJ conversion pathway and estimate the commercial feasibility, the economics of the fuel upgrading processes such as dehydration, oligomerization, dimerization, and hydrogenation 
also have to be considered. Because these processes are still under development, more research efforts are required to complete this target.

\subsubsection{Life-Cycle Assessment}

LCA studies for the ATJ process are primarily focused on production of ethanol [96] [97], n-butanol [98], and iso-butanol [92]. The LCA for fuel alcohol production can be categorized into four areas [92]: (1) feedstock (land-use-change), (2) on-site enzyme production, (3) biorefinery process, and (4) biorefinery co-product credits. If different pathways are considered, the biochemical process has slightly different performance from the thermochemical process with respect to GHG emissions, fossil fuel consumption and water consumption. [99].

For n-butanol and iso-butanol conversion, studies have focused on emissions, consumptive water use, global warming potential, and fossil energy consumption [92]. The n-butanol production process releases more direct emissions, such as $\mathrm{CO}_{2}$, nitrogen dioxide, and sulfur dioxide, than the iso-butanol production process does. $\mathrm{CO}_{2}$ is produced during the cellulase (or enzyme) production and cellulase seed fermentation, but is largely from combustion [92]. Nitrogen dioxide is formed through high temperature oxidation of the diatomic nitrogen in the combustion air. Sulfur dioxide emissions strongly depend on the amount of sulfuric acid used in the pretreatment process. However, the bio-refining of n-butanol consumes more water than iso-butanol refining does. The biomass feedstock is responsible for most of the global warming potential and fossil energy consumption [92]. Conversion of iso-butanol consumes 5.15 MJ/GGE more fossil fuel than n-butanol conversion does.

The LCA of the ATJ fuel upgrading processes is still unknown and requires more attention in future studies.

\subsection{Oil-to-Jet (OTJ) Fuel}

In this review, three processes are classified into the OTJ conversion pathway: HRJ, also known as HEFA; catalytic hydro-thermolysis $(\mathrm{CH})$, also termed hydrothermal liquefaction; and hydro-treated depolymerized cellulosic jet (HDCJ), also known as fast pyrolysis with upgrading to jet fuel. Currently, only products from the HRJ pathway have been approved for blending and have a defined ASTM specification.

\subsubsection{Process Description}

Both HRJ and $\mathrm{CH}$ processes employ triglyceride-based feedstocks, but the free fatty acids (FFAs) are produced differently. FFAs in the HRJ process are made by propane cleavage of glycerides, whereas in the $\mathrm{CH}$ process FFAs are formed by thermal hydrolysis. The bio-oil in the HDCJ process is produced by pyrolyzing the biomass feedstock. The downstream hydro-treating processes are similar in all three processes. The HRJ, $\mathrm{CH}$, and HDCJ processes are discussed separately below.

\subsubsection{Hydroprocessed Renewable Jet (HRJ)}

HRJ conversion technology is at a relatively high maturity level, is commercially available, and was recently used to produce jet fuel for military flights [57]. HRJ fuel is equivalent to conventional petroleum in properties, but has the advantages of higher cetane number, lower aromatic content, lower sulfur content, and potentially lower GHG emissions [100].

Over the past 60 years, a large variety of catalytic hydrogenation, deoxygenation, hydro-isomerization, and hydrocracking processes have been successfully developed and commercialized. A representative process flow diagram is shown in Figure 2. Renewable fats and oils that have different degrees of unsaturation require the hydrogenation process to completely saturate the double bonds [32]. Catalytic hydrogenation could be used to convert liquid-phase unsaturated fatty acids or glycerides into saturated ones [32] with the addition of hydrogen. The next step is to cleave the propane and produce three moles of FFAs [100]. The glycerol portion of the triglyceride molecule is turned into propane by adding $\mathrm{H}_{2}$. Alternative route to convert the glycerides to FFAs is thermal hydrolysis [101-103]. Oils and fats that contain mostly triglycerides are converted into three moles of FFAs and one mole of glycerol by 
processing the feedstocks with three moles of water. The hydrogen ion from the water is attached on the glycerol backbone and forms one mole of glycerol, where the hydroxyl ion from the water is added to the ester group and produces three moles of FFAs. High temperature $\left(250^{\circ} \mathrm{C}-260^{\circ} \mathrm{C}\right)$ is required for water to dissolve in the oil phase. High pressure is also necessary to maintain the reactants in liquid phase. The byproduct glycerol has many pharmaceutical, technical, and personal care product applications. The glycerol purification process is energy intensive, adding cost to overall process, but might be offset by glycerol selling value [104].

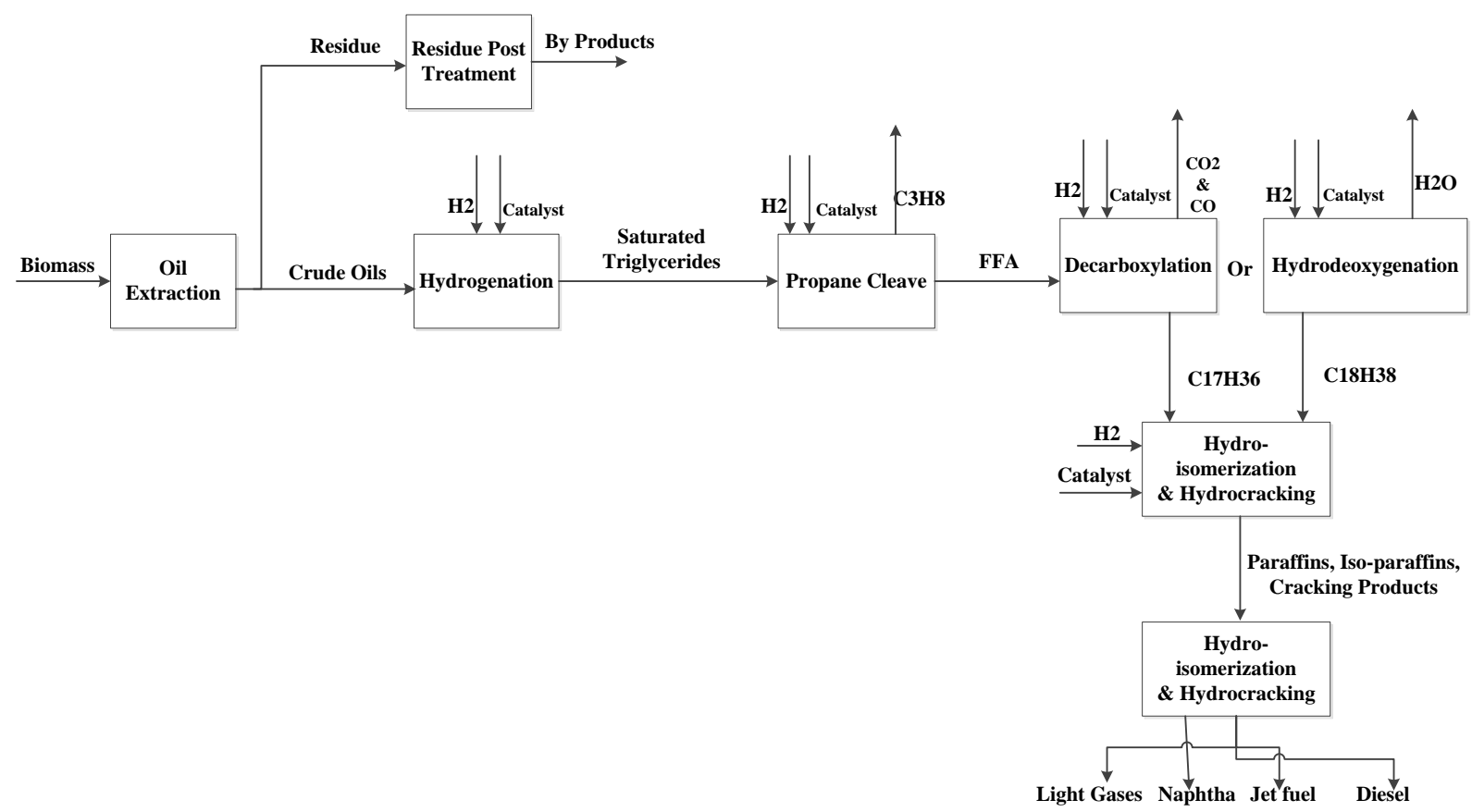

Fig. 2. Hydro-processed renewable jet (HRJ) process

To meet the jet fuel specification, the produced bio-jet fuel has to have not only a high flash point, but also good cold flow properties. Therefore, it is required to hydrocrack and hydro-isomerize the normal paraffins produced from deoxygenation to a synthetic paraffinic kerosene (SPK) product with carbon chains ranging from $C_{9}$ to $C_{15}$ [100]. The cracking and isomerization reactions are either concurrent or sequential [32]. Studies have shown that isomerization of straight-chain alkanes occurs first and cracking is a consecutive reaction. The isomerization process takes the straight-chain hydrocarbons and turns them into the branched structures to reduce the freeze point to meet the jet fuel standard [105]. It is accompanied by a hydrocracking reaction, which results in more or less yield from the isomerized species. The hydrocracking reactions are exothermic and result in the production of lighter liquids and gas products. They are relatively slow reactions; thus, most of the hydrocracking takes place in the last section of the reactor. The hydrocracking reactions primarily involve cracking and saturation of paraffins. Overcracking will result in low yields of jet-fuel-range alkanes and high yields of light species ranging from $C_{1}$ to $C_{4}$ and naphtha ranging from $C_{5}$ to $C_{8}$. Both of these are out of jet fuel range and also have lower economic value than diesel or jet fuel.

Bifunctional catalysts containing metallic sites for hydrogenation/dehydrogenation and acid sites for skeletal isomerization via carbenium ions are used in isomerization. In a typical isomerization reaction, normal paraffins are dehydrogenated on the metal sites of the catalyst and reacting on the acid sites to produce olefins protonate with formation of the alkylcarbenium ion. The alkylcarbenium ion is rearranged to monobranched, dibranched, and tribranched alkylcarbenium ions on the acid site. The branched alkylcarbenium ions are deprotonated and hydrogenated to produce the corresponding paraffins [106]. The choice of catalyst will result in variation of cracking at the end of the paraffin molecule and therefore adjust the yield of jet fuel range product [32]. The hydro-isomerization and hydrocracking processes are 
followed by a fractionation process to separate the mixtures to paraffinic kerosene (HRJ SPK), paraffinic diesel, naphtha, and light gases.

\subsubsection{Catalytic Hydrothermolysis $(\mathrm{CH})$}

Catalytic hydro-thermolysis $(\mathrm{CH})$, also named hydrothermal liquefaction, is a novel process that has been developed and patented by Applied Research Associates, Inc., for producing "renewable, aromatic, and drop-in" fuels (known as ReadiJet or ReadiDiesel) from plant or algal oils [51]. The hydrothermal process (Figure 3), contains a series of reactions, including cracking, hydrolysis, decarboxylation, isomerization, and cyclization, that turn triglycerides into a mixture of straight chain, branched, and cyclic hydrocarbons [107]. The $\mathrm{CH}$ reaction is conducted at temperatures from $450^{\circ} \mathrm{C}$ to $475^{\circ} \mathrm{C}$ and pressures of 210 bar with water and a catalyst (or without a catalyst). The resulting products-including carboxylic acids, oxygenated species, and unsaturated molecules - are sent to decarboxylation and hydro-treating processes for saturation and oxygen removal. The treated products, ranging from 6 to 28 carbon numbers, contain nalkanes, iso-alkanes, cyclo-alkanes, and aromatics, which require a fractionation step for separation to naphtha, jet fuel, and diesel fuel. The jet fuel made from the $\mathrm{CH}$ process meets ASTM and military (MIL) specifications and has excellent combustion quality, cold flow properties, and stability [50]. Research has shown that through the $\mathrm{CH}$ process, bio-jet fuels can be produced from a variety of triglyceride-based feedstocks such as soybean oil, jatropha oil, camelina oil, and tung oil (shown in Table 4) [107, 108].

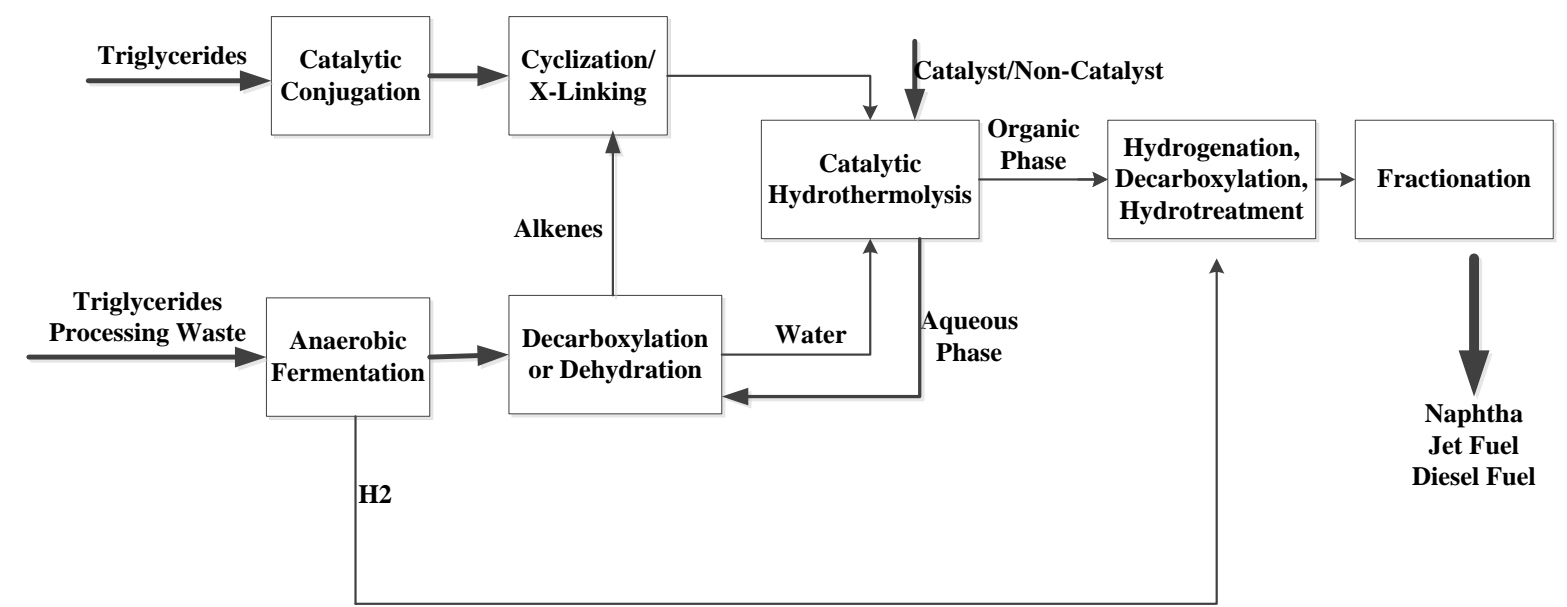

Fig. 3. Catalytic hydro-thermolysis to jet fuel [107, 108].

Table 4. Bio-jet Fuels from the CH Process [107, 108]

\begin{tabular}{|c|c|c|c|c|c|c|c|}
\hline & JP-8 & $\begin{array}{c}\text { From } \\
\text { Soybean }\end{array}$ & $\begin{array}{c}\text { From } \\
\text { Jatropha }\end{array}$ & $\begin{array}{l}\text { From } \\
\text { Tung } \\
\end{array}$ & $\begin{array}{c}\text { From } \\
\text { Camelina }\end{array}$ & $\begin{array}{c}\text { From } \\
\text { Carinata }\end{array}$ & $\begin{array}{l}\text { MIL-DTL-83133H } \\
\text { Spec Requirement }\end{array}$ \\
\hline Aromatics & $18.8(\operatorname{vol} \%)$ & $2.6(\mathrm{wt} \%)$ & $10.8(\mathrm{wt} \%)$ & $61.7(\mathrm{wt} \%)$ & $24.2(\operatorname{vol} \%)$ & $\begin{array}{c}16.8 \\
(\mathrm{vol} \%)\end{array}$ & $\leq 25.0$ \\
\hline Paraffins (normal + iso) & N/A & $40.0(\operatorname{vol} \%)$ & $32.8(\mathrm{wt} \%)$ & $16.2(\mathrm{wt} \%)$ & N/A & N/A & N/A \\
\hline Olefins & $0.8(\operatorname{vol} \%)$ & N/A & N/A & N/A & $1.3(\operatorname{vol} \%)$ & $1.8(\mathrm{vol} \%)$ & $\leq 5.0(\operatorname{vol} \%)$ \\
\hline Cycloparaffins & N/A & $52.0(\operatorname{vol} \%)$ & $39.2(\mathrm{wt} \%)$ & $16.7(\mathrm{wt} \%)$ & N/A & N/A & N/A \\
\hline Dicycloparaffins, vol\% & N/A & $5.9(\operatorname{vol} \%)$ & N/A & N/A & N/A & N/A & N/A \\
\hline Heat of Combustion, MJ/kg & 43.3 & 43.4 & 43.4 & 42.3 & 42.9 & 43.2 & $\geq 42.8$ \\
\hline Smoke Point, mm & 22 & $>30$ & 28 & N/A & 22 & 26 & $\geq 19$ \\
\hline Freeze Point, C & -51 & $<-47$ & -39 & $<-66$ & -54 & -57 & $\leq-47$ \\
\hline Flash Point, C & 51 & $>38$ & 45 & 39 & 48 & 46 & $\geq 38$ \\
\hline Distillation (D2887, D86) & N/A & pass & $195-229$ & $187-252$ & N/A & N/A & N/A \\
\hline Density, kg/L & 0.804 & $>0.775$ & 0.804 & 0.839 & 0.818 & 0.802 & $0.775-0.840$ \\
\hline
\end{tabular}




\begin{tabular}{lccccccc}
\hline & JP-8 & $\begin{array}{c}\text { From } \\
\text { Soybean }\end{array}$ & $\begin{array}{c}\text { From } \\
\text { Jatropha }\end{array}$ & $\begin{array}{c}\text { From } \\
\text { Tung }\end{array}$ & $\begin{array}{c}\text { From } \\
\text { Camelina }\end{array}$ & $\begin{array}{c}\text { From } \\
\text { Carinata }\end{array}$ & $\begin{array}{c}\text { MIL-DTL-83133H } \\
\text { Spec Requirement }\end{array}$ \\
\hline Acid Number, mg of KOH/g & 0.003 & $<0.010$ & $<0.010$ & N/A & 0.011 & 0.012 & $\leq 0.015$ \\
Hydrogen, wt\% & 13.8 & N/A & 14 & 13.3 & 13.8 & & $\geq 13.4$ \\
Viscosity at -40C, cSt & 9.9 & N/A & N/A & N/A & 7.4 & 6.5 & $\leq 12.0$ \\
Cetane Index & N/A & N/A & 43.9 & 34.2 & N/A & N/A & N/A \\
\hline
\end{tabular}

\subsubsection{Hydro-treated Depolymerized Cellulosic Jet (fast pyrolysis with upgrading to jet fuel)}

Hydro-treated depolymerized cellulosic jet (HDCJis a recent technology developed by Kior to convert the cellulosic biomass into renewable gasoline, diesel, and jet fuels [52]. The HDCJ jet fuel has not yet been approved by ASTM. Bio-oils from the pyrolysis process undergo a series of hydro-treating processes to produce jet-fuel-range products. If no further catalytic upgrading is applied, pyrolysis oils undergo hydrotreating and fractionation to form jet blend stocks, as shown in Figure 4. In addition, UOP LLC, PNNL, Ensyn, and Tesoro have been working on upgrading pyrolysis oil to hydrocarbon fuels, including jet fuel, through integrated pyrolysis and hydro-conversion [109-111]. Utilizing feedstocks including corn stover, cane bagasse, switchgrass, guinea grass, algae biomass, and forest residue, this integrated biorefinery system combines commercial RTP (Rapid Thermal Processing) pyrolysis technology with catalytic hydro-conversion. Approximately 42.4-44.2 wt\% jet fuel was separated by batch vacuum distillation [109-111].

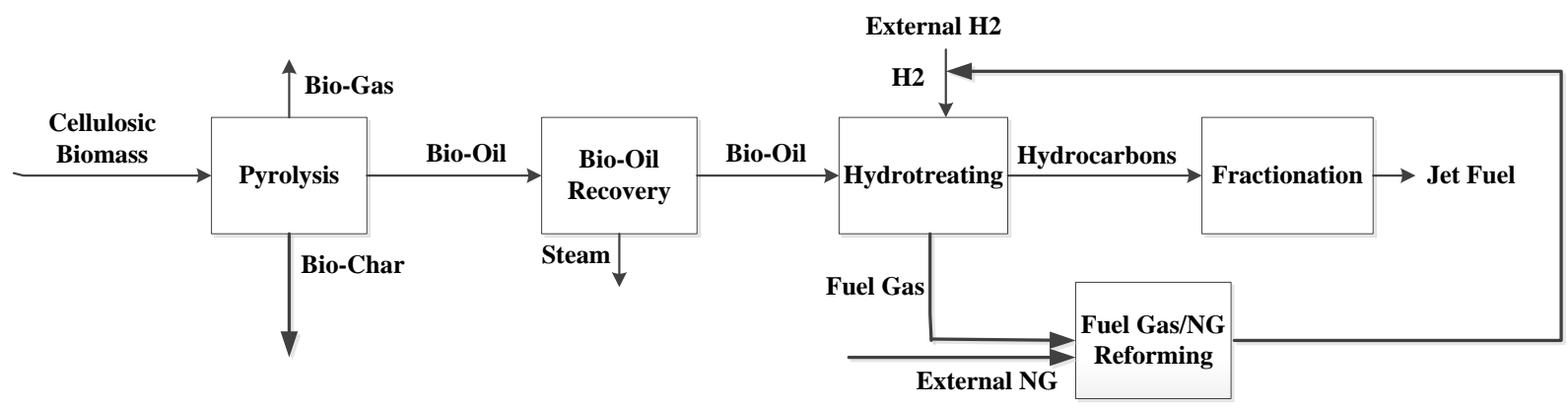

Fig.4. Pyrolysis-to-jet process [52]

\subsubsection{Economic Analysis}

An economic analysis of HRJ fuel is described in the literature [112]. The HEFA fuel price was found to be $\$ 3.85 / \mathrm{gal}$ (\$4.1/gal or $\$ 3.6 / \mathrm{GGE}$ on 2011 U.S. dollars) for the plant capacity of $98.28 \mathrm{MM}$ gal/yr and $\$ 4.46 /$ gal ( $\$ 4.8 / \mathrm{gal}$ or $\$ 4.2 / \mathrm{GGE}$ on 2011 U.S. dollars) for the plant capacity of $30.16 \mathrm{MM}$ gal/yr. Additional $\$ 0.27 / \mathrm{gal}-\$ 0.31 / \mathrm{gal}$ is required to produce maximum jet fuel because of the increased hydrogen use and decreased yields of jet and diesel fuels. The economic analysis of bio-jet fuels from microalgae and pongamia oils are also studied [113]. The minimum selling prices for jet fuels derived from microalgae and pongamia oils are estimated to be $\$ 31.98 /$ gallon or $\$ 28.3 / \mathrm{GGE}$ and $\$ 8.9 /$ gallon or \$7.9/GGE (2011 U.S. dollars), respectively. The development of technology and market will decrease the prices to be $\$ 9.2 /$ gallon or $\$ 8.1 /$ GGE and $\$ 6.07 /$ gallon or $\$ 5.4 /$ GGE (2011 U.S. dollars), respectively. Unlike biodiesel production through transesterification, HRJ biofuel production requires hydrogen to hydro-treat the biomass. It is suggested that the capital cost for HRJ is $20 \%$ higher than that of biodiesel production due to the hydro-treating process. However, the by-products from HRJ - naphtha, liquefied petroleum gas, propane, and diesel-have more credits than glycerol from the transesterification process [55]. Feedstock costs contribute a significant part of the production cost. For example, $70 \%-80 \%$ of the total production cost for biodiesel production results from the cost of feedstocks [114-117]. Edible and non-edible oils are becoming promising alternatives to biofuel because they are renewable in nature and can be produced locally and in environmentally friendly ways. Table 5 shows the unit oil prices for plant oils, algae oil, waste cooking oil, and pyrolysis oil. Obviously, higher oil yield leads to lower operating cost. 
Table 5. Oil Selling Price [118-123]

\begin{tabular}{lllllllll}
\hline & Jatropha & Palm & Camelina & Algae & $\begin{array}{l}\text { Waste Cooking } \\
\text { Oil }\end{array}$ & Soybean & Rapeseed & Pyrolysis Oil \\
\hline $\begin{array}{l}\text { Oil Price } \\
\text { (\$kg) }\end{array}$ & 0.50 & 0.79 & 1.75 & 3.55 & $0.115 \sim 0.472$ & 1.14 & 1.72 & 0.26 \\
\hline
\end{tabular}

By-products from the HRJ process can be upgraded to increase overall yield or sold as a high-value-added co-product. Depending on the conversion technology, the by-products include:

1. Propane, which is created by breaking the carbon backbone of the triglyceride or formed in the fractionation step. It accounts for $4 \%$ of the products [100]. The current residential propane price is $\$ 2.48 / \mathrm{gal}[124]$.

2. Liquefied natural gas (LNG), which is produced in the product separation step. LNG will increase to $6 \%$ if the diesel fuel is cracked down to the jet fuel range [100]. The current price of LNG is $\$ 4.58$ per thousand cubic feet [125].

3. Naphtha, which is also formed in the distillation step. The price of naphtha is $\$ 2.03 /$ gal [100].

4. Diesel, which is separated in the fractionation step. The current price of biodiesel is around \$3.64/gal [126].

\subsubsection{Life-Cycle Assessment}

Several research groups have developed a GHG emissions analysis on a life cycle basis [3, 56, 100, 127]. The GHG emissions for soybean oil are about $40 \%$ to $80 \%$ of those of conventional jet fuel (89 $\mathrm{gCO}_{2} \mathrm{e} / \mathrm{MJ}$ for Jet A fuel ) [56], resulting from the soybean yield, $\mathrm{N}_{2} \mathrm{O}$ emissions from fertilizer, liming emissions, and $\mathrm{H}_{2}$ requirements in the hydro-treating process. The GHG emissions increase when land use change is considered. One study shows low soybean yield from tropical rainforest results in $800 \%$ more emissions than conventional jet fuel [56]. The emissions of the palm oil to jet fuel process are about $30 \%$ to $40 \%$ of those of conventional jet fuel production processes, resulting from palm fresh-fruit-bunch yield per acre, farming energy, methane emissions from palm oil-mill effluent treatment, $\mathrm{H}_{2}$ requirements in the hydro-treating process, and hydro-processing fuel yield. GHG emissions increase to the range of $40 \%$ to $800 \%$ of those of conventional jet fuel when accounting for land use change [3]. For rapeseed oil, the emissions are around $45 \%$ to $87 \%$ of those of conventional jet fuels [3] and increase to $87 \%$ to $147 \%$ when considering land use change. For jatropha oil, the emissions are $36 \%$ to $52 \%$ of those from conventional jet fuel, and $\mathrm{N}_{2} \mathrm{O}$ emissions represent more than $20 \%$ of the total emissions. Zero emissions from land use change are assumed due to the assumption that marginal land will be used. Other research shows the emissions from jatropha OTJ conversion were $40 \mathrm{gCO}_{2} \mathrm{e} / \mathrm{MJ}$ of fuel produced [127], approximately $45 \%$ of that of conventional jet fuel. For algal oil, the emissions range from $16 \%$ to $220 \%$ of those from conventional jet fuel. The wide range results from the uncertainty of emissions from $\mathrm{CO}_{2}$ injection and dewatering and drying processes [3]. For salicornia oil, the emissions range from $35 \%$ to $76 \%$ of those from conventional jet fuel [3]. The GHG emissions of liquid fuel production via fast pyrolysis of cellulosic biomass have been studied by researchers at Argonne National Laboratory [128]. When hydrogen is generated from natural gas and bio-char is used to support the process energy, the GHG emissions are reduced by $45 \%$ relative to conventional fuels. When hydrogen is produced from reforming of pyrolysis oil and bio-char is applied as the fertilizer, the GHG emissions are reduced by $103 \%$ relative to conventional fuels [128].

\subsection{Gas-to-Jet (GTJ) Fuel}

The GTJ pathway presented here describes the conversion processes that turn biogas, natural gas, or syngas into bio-jet fuel. The F-T and gas fermentation processes are classified in this pathway and are reviewed here. 


\subsubsection{Process Description}

\subsubsection{Fisher Tropsch Biomass to Liquid (FT-BTL) Process}

The F-T process is capable of producing liquid hydrocarbon fuels from syngas. F-T fuels are typically free of sulfur and contain very few aromatics compared to gasoline and diesel, which leads to lower emissions when used in jet engines [12]. Some recent studies point out that the use of the F-T technology to convert biomass to synthetic fuels may provide a promising carbon-neutral alternative to conventional diesel, kerosene, and gasoline [129-131]. The process reviewed here is the FT-BTL process.

In the FT-BTL process (Figure 5), biomass feedstocks are first dried to reduce the particle sizes during pretreatment [132]. Multiple gasification technologies exist to convert the biomass to syngas. In a hightemperature (slagging) gasification process, the dried biomass is pressurized and converted into raw synthesis gas during gasification at temperatures around $1300 \mathrm{C}$ in the presence of high purity oxygen and steam. A combustor is included to provide heat to dry the biomass. The direct-quench syngas cooling system next to the gasifier removes ash and tars. A water-gas-shift system after quench is applied to adjust the $\mathrm{H}_{2}$ : $\mathrm{CO}$ ratio to $2.1: 1$ [132]. NREL has conducted an investigation on indirect gasification and tar reforming [85]. In this design, the endothermic gasification process is indirectly-heated by the circulation of hot olivine and the material in the gasifier is fluidized by the steam. Gasification occurs at atmospheric conditions and at $880^{*} \mathrm{C}$. The syngas is further conditioned such that the residual tars, methane and light hydrocarbons are reformed to syngas in a fluid catalytic cracker. Water gas shift also occurs in the reformer. Compared to the high temperature gasification, this design has the benefits of energy self-sufficient, improved capital cost associated with the smaller process scale, and neutral electrical energy [86].

After syngas is produced, it is polished with zinc oxide and an activated carbon sorbent and compressed to 25 bar, the F-T operating pressure. $\mathrm{H}_{2}$ used in hydro-processing stage can be purified through a pressure swing adsorption. The syngas is then processed by F-T synthesis to produce liquid fuel [129, 131], as illustrated in Figure 5.

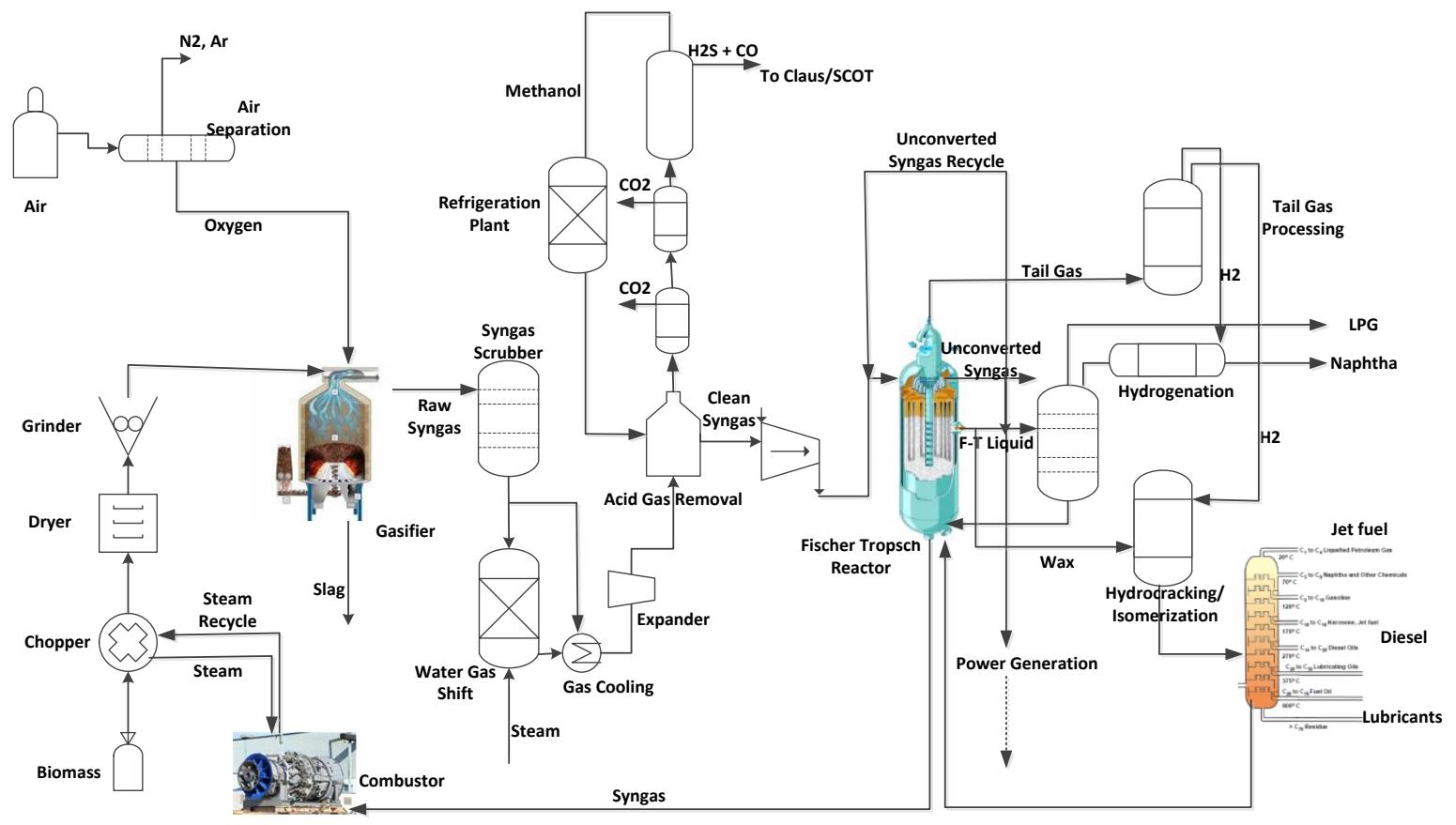

Fig. 5. FT-BTL process [133]

F-T synthesis is a set of catalytic processes for converting syngas into liquid hydrocarbons. There are two well-known F-T operating modes [134]; high temperature and low temperature. The high-temperature 
process runs at $300^{\circ}-350^{\circ} \mathrm{C}$ with iron-based catalysts. Gasoline and linear low-molecular-mass olefins are produced in this process. The low-temperature process operates at $200^{\circ}-240^{\circ} \mathrm{C}$ with either iron or cobalt catalysts. Linear waxes produced in the low-temperature process have higher molecular mass than those produced in the high-temperature process. In the F-T process, the products range from methane to longchain hydrocarbons. Besides alkanes and alkenes, oxygenated compounds such as alcohols, aldehydes, and carboxylic acids are also formed. Aromatics and ketones are also produced in the high temperature process. The F-T process is a highly exothermic process; therefore, the heat of reaction has to be removed quickly to avoid overheating and deactivating the catalyst and also to prevent production of undesired methane [135]. Traditional F-T catalysts, such as iron-, cobalt-, nickel- and ruthenium-based catalysts, have been extensively studied in the literature [130, 134, 136-143]. Product selectivity and product distribution depend strongly on the operating temperature and the partial pressure of the gases that contact the catalyst.

After F-T synthesis, a portion of the unconverted syngas is returned to the F-T reactor, and part of it is sent to the acid gas removal system [131]. The remaining portion flows into the power generation area, providing power for the air separation unit [131]. Conventional refinery processes, such as hydrocracking, isomerization, hydrogenation, and fractionation, can be applied to upgrade the F-T synthesis product to high-quality, low-aromatic, and almost zero-sulfur-content fuels [144]. Hydrocracking/isomerization is used to convert the wax into lighter products with shorter chain length and lower boiling points. Products from the hydrocracking/isomerization reactor are heated and distilled to produce jet fuel, diesel fuel, and lubricants. Hydrogenation is applied to produce naphtha from the F-T liquid. The F-T tail gas, which contains $\mathrm{H}_{2}$, water, methane, $\mathrm{CO}, \mathrm{CO}_{2}$, nitrogen, argon, and heavier hydrocarbons, is recycled back to the syngas generation system. $\mathrm{H}_{2}$ in the tail gas can be purified through the pressure swing absorber and can be further used in the hydrocracking/isomerization process.

\subsubsection{Gas Fermentation Process}

Instead of catalytically upgrading F-T syngas to bio-jet fuel, it is also possible to ferment syngas to liquid biofuels (Figure 6). If lignocellulosic biomass is used as the feedstock, it is first converted into syngas via gasification. The cooled syngas can be fermented to ethanol or butanol by acetogenic bacteria [145]. The acetogenic bacteria Clostridium is used to consume $\mathrm{CO}$ and $\mathrm{H}_{2}$ to produce ethanol and 2,3-butanediol [145]. Other products such as acetate, acetone, isopropanol, and butanol can be produced by other biosynthetic pathways with different microbe strains [146]. The mixed alcohol, ethanol, or 2,3-butanediol can be upgraded into jet fuel via the ATJ technology described in Section 2.1.2, which includes dehydration, oligomerization, distillation, and hydrogenation processes [147]. Gas fermentation has several potential advantages. It is able to produce more products than the traditional biochemical or thermochemical pathways can [148], and it has an overall energy efficiency of 57\%, while the F-T process has a relative overall energy efficiency of $45 \%$ [146]. The process requires lower temperature and pressure, as well as less expensive enzymes [148]. Gas fermentation can convert not only energy crops and typical agricultural wastes, but also municipal and industrial organic waste [148].

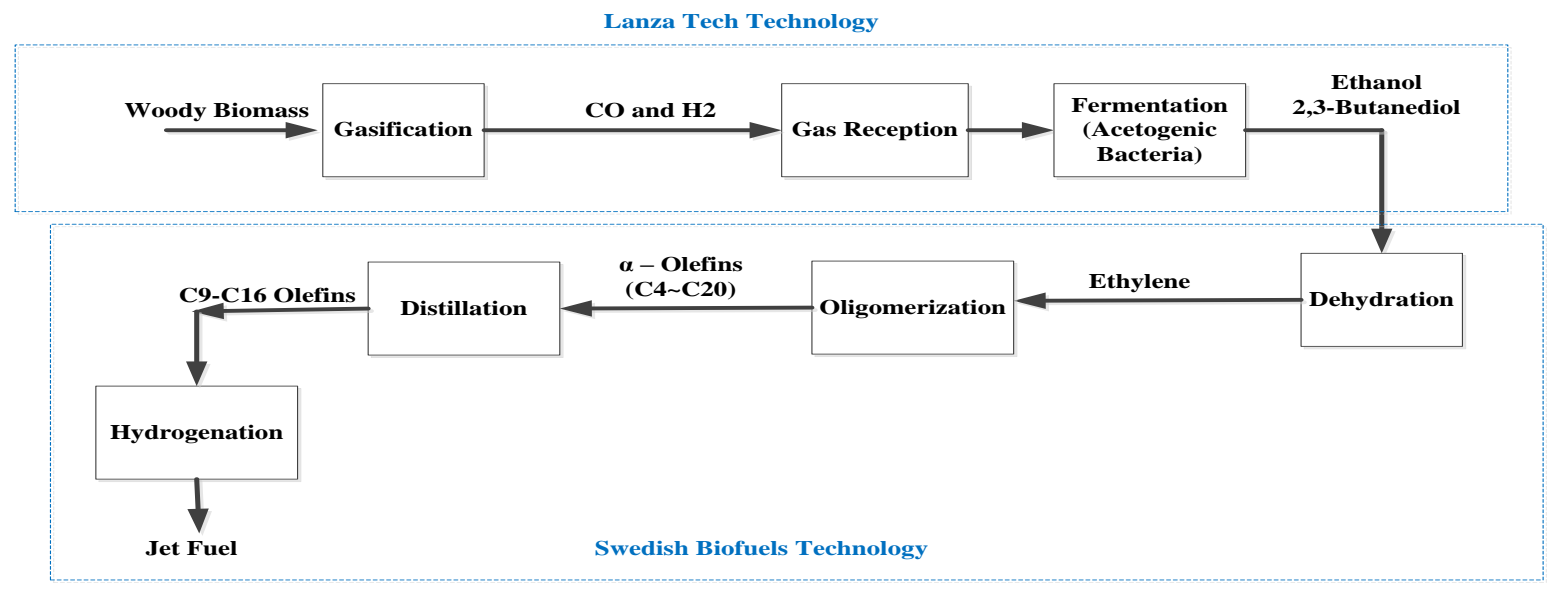


Fig. 6. Gas fermentation to bio-jet fuel

\subsubsection{Economic Analysis}

The production cost of BTL jet fuel has been reported based on BTL diesel production due to the similarity of the processes [12]. The feedstock price, as shown in the report, has a significant effect on the cost of the BTL fuel. High-cost energy crops contribute about $70 \%$ more to the cost of the fuel than highcost forestry residues and wastes [12]. In addition, production costs are reduced with the reduction of the conversion cost and improvement of the energy crop yield. It is estimated that the conversion cost will be reduced by $26 \%$ from 2012 to 2026 [12]. The unit production cost of BTL is expected to be higher than that of CTL due to the lower energy efficiencies with smaller plants and the higher capital cost of gasification [56]. The jet fuel production cost of CTL is estimated as $\$ 1.70$ to $\$ 2.04 /$ gal ( $\$ 2.26$ to $\$ 2.72 /$ gal on 2011 U.S. dollars), whereas for CBTL it is estimated as \$1.99/gal to \$2.34/gal (\$2.65 to $\$ 3.11 /$ gal on 2011 U.S. dollars) [56]. The temperature of gasification also has a high impact on the cost analysis of the BTL F-T process [90, 149]. A low-temperature gasifier has several constraints, such as the limitation of reaction kinetics and the formation/flow of slag [90]. Based on processing 2,000 metric tons per day of corn stover, the total capital investment for the high-temperature $\left(1,300^{\circ} \mathrm{C}\right)$, slagging, entrained flow gasification process, including feedstock handling, solids feeding, gasification, amine scrubbing, sour water-gas-shift, pressure swing adsorption, F-T synthesis, hydrocracking, and air separation/power generation, is $\$ 500$ million (2007 basis) [149]. The total capital investment for the low temperature $\left(870^{\circ} \mathrm{C}\right)$, non-slagging, direct fluidized bed gasification process is $\$ 610$ million. With the same capacity, high-temperature $\left(1,300^{\circ} \mathrm{C}\right.$ ) indirect gasification has total capital investment of $\$ 516$ million (2007 basis) [85]. Compared to the pyrolysis and biochemical processes, gasification has the highest capital cost [150]. Followed by catalytic F-T synthesis and hydro-processing to naphtha-range and distillate-range liquid fractions, the product values for the high temperature and low temperature direct gasifiers are $\$ 4.50 / \mathrm{GGE}$ and $\$ 5.00 / \mathrm{GGE}$ (\$5.50/GGE and \$6.10/GGE on 2011 US dollars), respectively. Tijmensen et al. [151], pointed out that the pretreatment, gasification with oxygen, and gas cleaning sections account for approximately $75 \%$ of total capital cost. The production cost of F-T liquids in this study ranged from $\$ 9 / \mathrm{GJ}$ to $\$ 16 / \mathrm{GJ}$ (\$1.86/gal to $\$ 3.30 /$ gal on 2011 US dollars).

\subsubsection{Life-Cycle Assessment}

In the syngas production and fuel synthesis processes, the GHG emissions considered are [152] (1) $\mathrm{CO}_{2}$ emissions from gasification, F-T synthesis, fossil fuel combustion, and venting from natural gas production; (2) methane emissions from fugitive plant and pipeline emissions, incomplete combustion, and coal bed methane releases; and (3) $\mathrm{N}_{2} \mathrm{O}$ emissions from fuel combustion and the cultivation of biomass. The F-T CTL and F-T GTL processes have high life-cycle GHG emissions $[152,153]$. The F-T CTL process has GHG emissions 10\% higher than those of conventional jet fuel with carbon capture and $120 \%$ higher without carbon capture. GHG emissions from the F-T BTL process are 92\%-95\% less than those of conventional jet fuel because the feedstock for F-T BTL, either woody biomass or forestry residues, has a very low contribution [12]. This is also because $48 \%$ of the energy consumed for the conversion processes, either gasification or F-T synthesis, comes from the biomass itself [12]. The lifecycle GHG emissions from the use of corn stover, forest residue, and switchgrass are 9.0, 12.2, and -2.0 $\mathrm{gCO}_{2} \mathrm{e} / \mathrm{MJ}$, respectively (with a soil carbon-change credit, the $\mathrm{CO}_{2}$ sequestration arising from land use change dominates the GHG emissions), which are about 10\%, 14\%, and $-2 \%$ of those of conventional jet fuel, respectively [3]. It is also suggested that identifying strategies and technologies, such as carbon sequestration, co-production of fuels and power, co-processing of coal and biomass, and improved vehicle technology will help reduce GHG and other emissions from the F-T process [154]. When switchgrass is used as the feedstock, the WTW GHG emissions range from $11.9 \mathrm{gCO}_{2} \mathrm{e} / \mathrm{MJ}$ to $26 \mathrm{gCO}_{2} \mathrm{e} / \mathrm{MJ}$ without soil carbon sequestration and from $-1.7 \mathrm{gCO}_{2}$ to $-4.4 \mathrm{gCO}_{2} \mathrm{e} / \mathrm{MJ}$ with soil carbon sequestration [3]. HRJ fuel has higher GHG emissions, about 62\%-92\% more than F-T BTL [21] due to higher fertilizer and chemical use. The effect of carbon capture and storage on climate, estimated in terms of radiative forcing 
of the production and utilization chains of the F-T fuel based on GHG emissions, has been studied [155]. It is concluded that without carbon capture and storage, the climate impacts of F-T fuel from peat are $30 \%-40 \%$ lower than from petroleum fuels. With carbon capture and storage, the climate impacts of peatbased F-T fuels are 50\%-84\% lower than petroleum diesel.

\subsection{Sugar-to-Jet Fuel}

The biological and catalytic conversion of sugars to hydrocarbons provide a biochemical route to the production of liquid transportation fuels and chemicals [17, 43-48, 156, 157]. According to reports by DOE's Office of Energy Efficiency \& Renewable Energy Bioenergy Technologies Office [39, 40], STJ fuel can be processed via two pathways:

1. Catalytic upgrading of sugars or sugar intermediates to hydrocarbons: sugars are separated from biomass (e.g., milled corn stover) through a series of chemical and biochemical processes and upgraded into hydrocarbon fuels through aqueous phase reforming (APR). The process has been operated by companies such as Virent and Virdia. The jet fuel produced from the process has been tested in AFRL and passed the relevant specifications of Jet A1 fuel.

2. Fermentation of sugars to hydrocarbons: the sugars from biomass are fermented directly to hydrocarbon fuels or hydrocarbon intermediates, recovered, purified, and further upgraded to drop-in hydrocarbon fuels. This process has been operated by companies such as LS9 and Amyris, and the renewable jet fuel produced by the process from a sugarcane feedstock has been used in an Embraer E195 jet operated by Azul Brazilian Airline [158].

\subsubsection{Process Description}

The STJ processes include (1) catalytic upgrading of sugars to hydrocarbons, (2) fermentation of sugars to hydrocarbons, and (3) sugar-to-sugar intermediate and upgrading to fuel.

\subsubsection{Catalytic Upgrading of Sugars to Hydrocarbons}

Lignocellulosic sugars are typically produced by pretreatment and enzymatic hydrolysis of biomass feedstocks. A certain level of purification and concentration of biomass sugars is often needed before catalytically upgrading sugar to hydrocarbons, which converts sugar or its intermediates to a range of hydrocarbon molecules and hydrogen in an APR process. The hydrocarbon molecules are separated in a fractionation process to jet, gasoline, and diesel fuels. Bio-derived chemicals, such as para-xylene for polyethylene-terephthalate-saturated polyester polymers, are also produced [40] and can be credited as co-products. Closed loop processes that recover and recycle the unreacted species are significant to improve the process economics [17], but separation of the product mixtures can be technically challenging.

Virent's BioForming platform is one example of a process that turns the plant sugars into high-energy hydrocarbon mixtures (Figure 7) [44, 48, 144, 159]. Following the pretreatment and fractionation processes, lignocellulosic biomass is converted and separated to cellulose, hemi-cellulose, and lignin. Lignin, in this process, is sent to the combustor to provide process heat. Using enzymatic or acid hydrolysis, the fractionated cellulose and hemicellulose are turned into sugars with five and six carbons. The carbohydrates are converted into polyhydric alcohols via hydrogenation [160] or short-chain oxygenates via hydrogenolysis [161]. The key step in the BioForming platform is APR. Through APR, the product stream from the hydro-treating step is reacted with water over a proper heterogeneous catalyst at temperatures of 450 to $575 \mathrm{~K}$ and pressures of 10 to 90 bar. The APR reaction includes reforming to produce hydrogen, dehydrogenation of alcohols/hydrogenation of carbonyls, deoxygenation, hydrogenolysis, and cyclization [161]. Products that form in APR are hydrogen, carbon dioxide, alcohols, ketones, alkehydes, alkanes, organic acids, and furans [162]. Hydrogen produced from APR will support the hydro-treating process before the APR step and hydro-refining processes after the APR step. The lighter alkanes from APR, such as $\mathrm{C}_{1}-\mathrm{C}_{4}$ hydrocarbons, are sent to the combustor to provide additional process heat [163]. 
Based on the available open literatures, there are three potential routes to convert the oxygenates from the APR step into jet-fuel-range hydrocarbons. As shown in Figure 7, the first route is acid condensation, which turns the oxygenates into alkanes, iso-alkanes, and aromatics with a zeolite ZSM-5 catalyst. The reactions include dehydration of oxygenates to alkenes, oligomerization of the alkenes to heavier alkenes, cracking, cyclization and dehydrogenation of heavier alkenes to aromatics, alkane isomerization, and hydrogen-transfer to form alkanes [162, 164, 165]. The heavier species of the products can be distilled and blended into jet fuel. The second route is direct catalytic condensation over multifunctional solid-base catalysts [81, 166]. There are several condensation reactions occurring: (1) aldol condensation to produce a $\beta$-hydroxyketone or $\beta$-hydroxyaldehyde, (2) dehydration of $\beta$-hydroxyketone or $\beta$-hydroxyaldehyde to produce a conjugated enone, (3) hydrogenation of the conjugated enone to produce ketone or aldehyde, and (4) removal of hydroxyls by dehydration/hydrogenation or hydrogenolysis to form alkanes [81, 166]. The products from this route are mostly in the jet fuel range. The third route is to convert the oxygenates from APR to alkanes and alkenes via dehydration and hydrogenation-dehydration reactions. The alkenes are oligomerized to produce kerosene with solid phosphoric or zeolite catalysts $[167,168]$.

To obtain high selectivity to fuels, a catalyst that helps generate hydrocarbons with low oxygen content and with the appropriate amount of branching, cyclic, and aromatic content is needed [17]. The catalyst should be able to deal with a wide range of sugars and contaminants, including sulfur, nitrogen and ash. In addition, the ideal catalyst should be able to handle lignin and its decomposed products with high carbon efficiency and long catalyst lifetime [17].

Researchers at the University of Wisconsin-Madison developed a two-stage process that converts sugar derived from biomass into 2,5-dimethylfuran (DMF) [169]. The fructose, obtained directly from biomass or by isomerizing of glucose, was dehydrated to form 5-hydroxymethylfurfural (HMF) by removing five oxygen atoms over an acid catalyst. HMF was then turned into DMF through hydrogenolysis over a CuRu catalyst. The resulting DMF has higher energy density by $40 \%$ and a higher boiling point by $20 \mathrm{~K}$ than ethanol, and it is not water soluble [169]. This study created a new path for the production of DMF as a replacement for traditional petroleum transportation fuels.

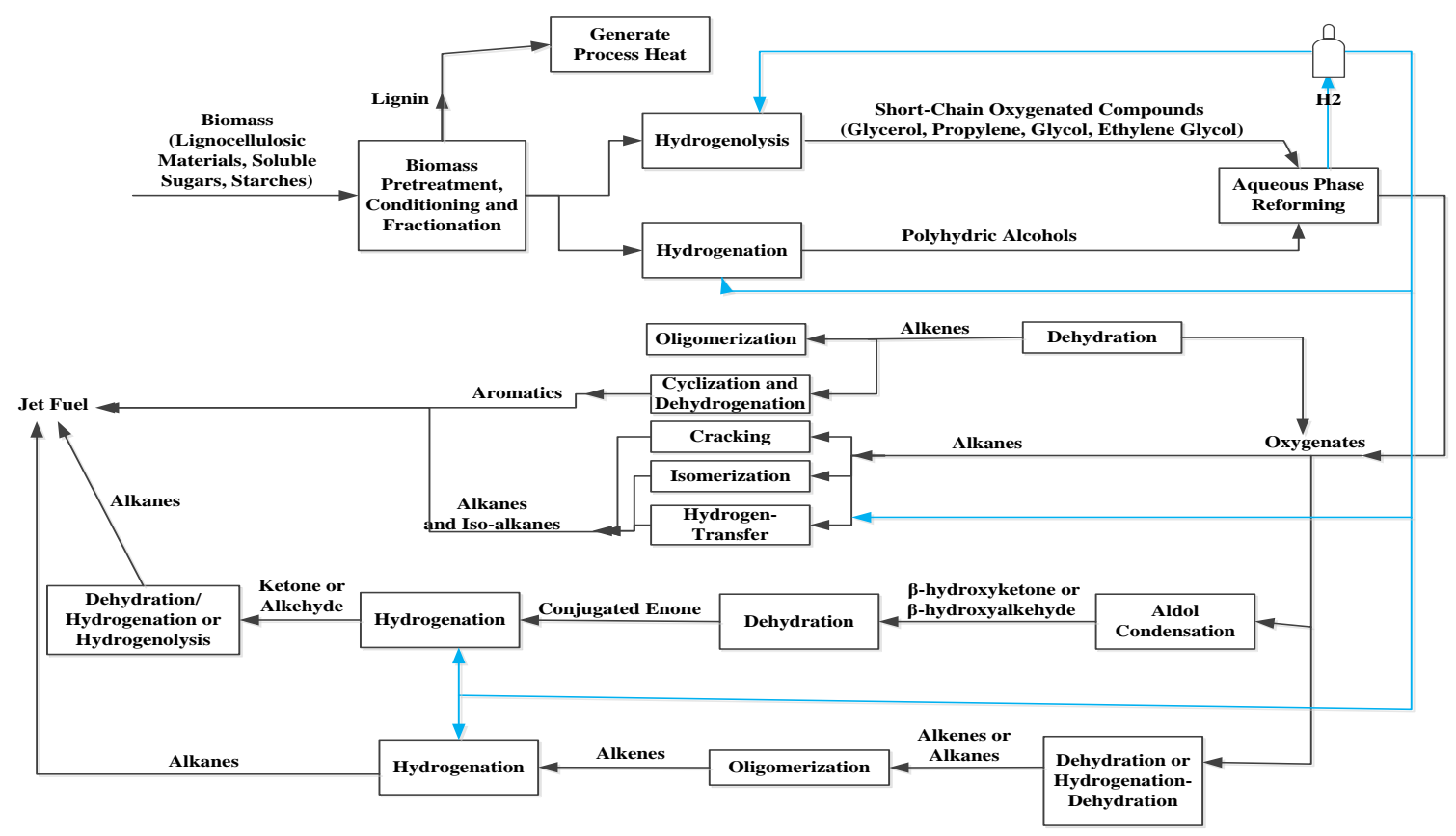

Fig. 7. Catalytic upgrading of sugars to jet fuel (Virent BioForming Process)

Note: Blue line represents the hydrogen supply 


\subsubsection{Direct Sugar to Hydrocarbons (DSH)}

In the direct sugar-to-hydrocarbons process, biomass cell walls are broken down and hemicellulose sugars are released. After enzymatic hydrolysis, which removes solid materials, liquid sugars are often concentrated by removing 50\% of the water. Hydrocarbon intermediates are produced by processing concentrated sugars through an aerobic fermentation process using fed-batch or continuous fermentation. The resulting products are then sent to a phase separation stage to recover the hydrocarbon fuels [39].

The processes developed by Amyris and LS9 successfully transforms sugars to hydrocarbon fuel [170, 171]. There are two pathways to produce isopentenyl pyrophosphate (IPP), the precursor of liquid fuel: the mevalonic acid (MVA) pathway and the deoxyxylulose-5-phosphate (DXP) pathway [172]. The threecarbon compound pyruvate derived from glycolysis of glucose is turned into three moles of acetyl-CoA. The mevalonate pathway employs three moles of acetyl-CoA and produces the five-carbon IPP [17]. The DXP pathway produces IPP via condensing pyruvate and D-glyceraldehyde-3-phosphate from glycolysis [17]. The DXP pathway has higher carbon efficiency (83\%) than the MVA pathway does (56\%) [17]. The terpenes, assembled by condensing IPP and its isomer dimethylallyl pyrophosphate, represent the candidates of biologically-derived fuel [17]. Large terpenes can be cracked to liquid fuel and the branched olefins can be hydrogenated to isoparaffins $[17,171]$. Figure 8 shows an example of sugar fermentation to hydrocarbons in which the sugar syrup is processed through the MVA and converted into artemisinic acid, isopentenyl pyrophosphate, and jet/gasoline precursors. The artemisinic acid is then turned into an anti-malarial drug, and isopentenyl pyrophosphate is further transformed into farnesenyl pyrophosphate and $\mathrm{C}_{15}$ isoprenoids, which are the precursors of diesel and chemicals [170]. The fermentation waste could be optionally processed with anaerobic digestion to reduce the effluent. After purification, through downstream hydro-processing, the jet/gasoline precursors can be turned into bio-jet fuel.

An engineered E. coli fatty acid pathway has been developed to produce fatty esters, fatty alcohols, and waxes from sugars $[17,173]$. Through combining the thioesterase-catalyzed hydrolysis of fatty acyl-ACP, with fatty acyl-CoA-synthase-catalyzed reactivation of the fatty acid carboxylate group, fatty acyl-CoA was converted from fatty acid metabolism. Fatty esters were produced by applying an acyltransferase with an alcohol-forming pathway; fatty alcohols were produced from fatty acyl-CoAs by expressing fatty acyl-CoA reductases; and wax was produced through the fatty alcohol pathway [173]. Through the pathway consisting of acyl-acyl carrier protein reductase and an aldehyde decarbonylase, the $\mathrm{C}_{13}-\mathrm{C}_{17}$ mixtures of alkanes and alkenes, part of the component of jet fuel, are produced from these intermediates of fatty acid metabolism [171]. This invention, developed by LS9, enables the conversion of biomass into jet fuels without the need for chemical conversion technologies such as distillation or hydrogenation.

Scientists in Berkeley have developed a novel process that integrates ABE fermentation and chemical catalysis to selectively produce jet, diesel, and gasoline products from lignocellulosic and cane sugars [73]. Glyceryl tributyrate has been used to efficiently separate acetone and n-butanol from ethanol and to remove several inhibitors of fermentation found in acid-pretreated lignocellulosic biomass, such as furfural, $p$-coumaric acid, and ferulic acid. Acetone and butanol from ABE fermentation are converted into ketone through a condensation reaction over $\mathrm{K}_{3} \mathrm{PO}_{4}$ and a palladium catalyst. The resulting products, a $\mathrm{C}_{11}$ compound with a ketone in the middle, can be fed into the refinery infrastructure as a feedstock to produce renewable jet fuel [73]. 


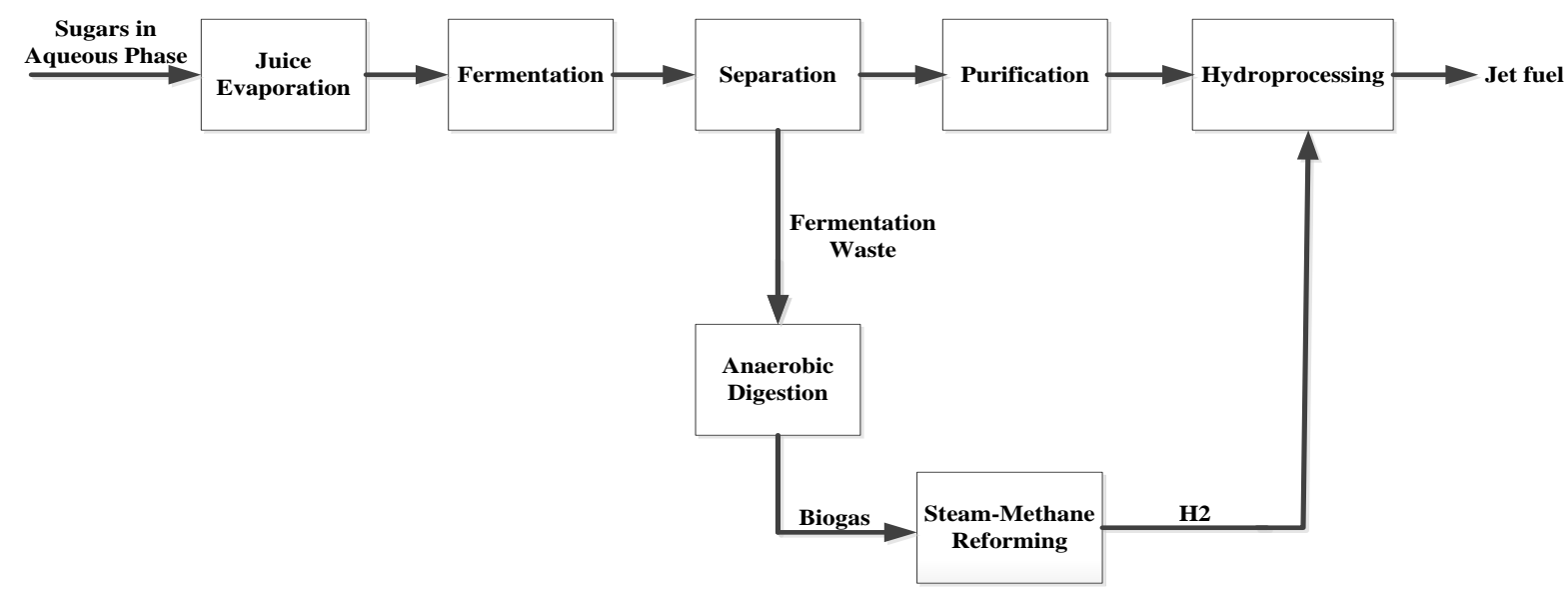

Fig. 8. Direct sugar-to-jet fuel

\subsubsection{Economic Analysis}

When analyzing the process economics of STJ, separation of the sugar and sugar intermediates from other compounds needs more attention [17]. Separation of decomposed biomass slurries sometimes accounts for 50\% 70\% of capital and operating costs at a biorefinery [174]. Decreasing viscosities, increasing fluxes, and avoiding formation of precipitants are ways to increase the efficiency of separation at high temperatures [174]. NREL and Virent are currently conducting a process economic analysis for Virent's BioForming technology [144]. Four main process steps, (1) pretreatment/fractionation, (2) hydrogenation, (3) APR, and (4) acid catalyzed dehydration/condensations, are considered to affect the production cost significantly [144]. Additionally, researchers from Iowa State University and the University of Wisconsin-Madison conducted a techno-economic study of DMF and HMF production [175]. Based on the process capacity of 300 metric ton/day of fructose and an operating period of 20 years, the resulting minimum selling prices for HMF and DMF were estimated to be $\$ 5.03 /$ gal ( $\$ 6.2 / \mathrm{gal}$ or $\$ 4.8 / \mathrm{GGE}$ on 2011 US dollars) and \$7.63/gal (\$9.4/gal or \$9.9/GGE on 2011 US dollars), respectively. The cost of the copper-ruthenium-carbon catalyst used in the DMF process might play an important role in the final production cost. This study provides a single point on the TEA associated with catalytic upgrading of a pure expensive clean sugar to a single product at a small scale. Other comparative analysis shows that the production of levulinic acid from biomass costs approximately $\$ 4.31 /$ GGE [176]. For the DSH pathway, the techno-economic analysis is conducted to evaluate the selling price of bio-jet fuel derived from sugarcane, resulting in $\$ 7.16$ /gallon (\$7.2/gal or $\$ 6.3 /$ GGE on 2011 US dollars) for the base case and $\$ 4.00$ /gallon (\$4.0/gal or $\$ 3.5 /$ GGE on 2011 US dollars) with the development of the technology and the market [113]. NREL in support of the NABC efforts, in collaboration with Virent and Amyris, is also conducting process economics studies for a direct sugar to fuel process [144]. The target is to find the low-cost routes for biomass hydrolysate streams and low-cost mitigation strategies for fermentation inhibitors that are compatible with the current state of the art. Future work should consider the catalytic upgrading of biomass-derived sugars to a slate of fuel components, specifically jet fuel.

\subsubsection{Life-Cycle Assessment}

The Institute for International Trade Negotiations conducted a study of life-cycle GHG emissions of biojet fuel produced from sugarcane sugars based on the Amyris process parameters [43]. The results showed that the life-cycle GHG emissions are around $15 \mathrm{gCO}_{2} \mathrm{e} / \mathrm{MJ}$, an approximate $82 \%$ reduction compared with conventional Jet A/A-1 fuels [43]. However, sugarcane could induce land use change, which was not considered in the study above. The GHG emissions associated with sugarcane production and transport, according to the study, are primarily dominated by farm input and the emissions of $\mathrm{N}_{2} \mathrm{O}$ from the soil, which contribute $32 \mathrm{gCO}_{2} \mathrm{e} / \mathrm{MJ}$ and $45 \mathrm{gCO}_{2} \mathrm{e} / \mathrm{MJ}$, respectively [41]. This research helps improve the knowledge of the carbon footprint of a renewable aviation fuel derived from sugarcane. 


\section{Summary of all bio-jet fuel production pathways}

Production yields, including intermediate and jet fuel yields, production costs and GHG emissions for the conversion technologies reviewed in this work are summarized in Table 6 for yields (details explained in Supplementary Materials), Table 8 for production cost and Figure 9 for GHG emission.

Feedstock is the most important parameter when considering the commercial feasibility of bio-jet fuel production. Agricultural and forest feedstocks as well as algal biomass are major feedstocks for producing alcohol fuels, able to provide large amounts of alcohols for converting into jet fuel. Plant oils, animal fats, waste cooking oils, algal oil, and pyrolysis oils are the predominant feedstocks for oil-related conversion processes such as HRJ, $\mathrm{CH}$, and HDCJ. Agricultural and forest residues can serve as major feedstocks for producing syngas or biogas. There is an abundance of sources of sugars (lignocellulosic or grain sugar) to ferment or synthesize to jet fuels via the STJ process. From the variable feedstocks, the sum of all the intermediates per dry ton biomass for each pathway is demonstrated in Table 6, using energy basis, i.e., GGE per dry ton biomass (BDT). Based on these literature data, ethanol from syngas fermentation has the highest reported yield (306.8 GGE/BDT) due to the $90 \%$ carbon conversion. On the other hand, algal oil has relatively low yield (22.5-29.9 GGE/BDT) because of the low oil content reported. Table 6 not only reports the yields of intermediates, but also summarizes the jet fuel yield after upgrading intermediates to finished products. The jet fuel yields demonstrate the jet fuel production from literature reported data or several assumptions for the calculating intermediates to jet productions. Detailed analyses can be found in the Supplementary Materials. For example, the jet fuel yield from palm seed results from the calculation of the product yield from palm oil through deoxygenation and hydro-treating processes. The jet fuel yield from corn stover derived isobutanol comes from the estimation of the product yield through dehydration, oligomerization and hydro-treating processes. For consistent purpose, the units are normalized from volumetric basis (gallon) to energy basis (GGE) by dividing the lower heating value (LHV) of the products (Table 7) by the LHV of gasoline. The yield values provide a general idea of the pathway/feedstock that most final products can be obtained from. The HRJ process with palm seed as the feedstock has the highest conversion from intermediate to final products $(67.8 \%)$ due to the high carbon conversion. The $\mathrm{CH}$ process with jatropha seed as the feedstock has the lowest intermediate-to-jet conversion $(8.0 \%)$ because most of the carbon distributes out of the jet fuel pool.

The maturity of a conversion process controls the process economics. FT-to-jet fuel (as an example of GTJ) has first been proved by ASTM as a promising technology. Product selection, which leads to the yield of jet fuel, is strongly dependent upon the operating temperature, partial pressure of syngas, and the applied catalyst. The HRJ process is also an approved process, representing one of the OTJ technologies. The use of hydrogen and selection of a catalyst contribute to a significant part of the production costs. ATJ and STJ processes are at the R\&D stage, and may be the next processes being approved. The jet fuel product yield, which depends on the catalyst or enzyme used, has attracted more and more interest and driven more research efforts.

The production cost for intermediates and final jet fuel from each pathway are summarized in Table 8. If the feedstock costs, financial assumptions, and analysis methodologies are not normalized, the cost numbers cannot be compared consistently. Both volumetric basis and energy basis units are presented in the table for consistency. All the cost numbers are adjusted to 2011 US dollars. Both the feedstock cost and conversion technology contribute a significant portion of each production cost. The STJ pathway has higher intermediate cost due to the early stage of technology development and the HDCJ (one of the OTJ technologies) has a lower intermediate cost because the selling price of pyrolysis oil is reported to be very low in the literature. As seen in the table, only HRJ and DSH processes have some reported numbers for jet fuel blendstock production cost. HRJ fuel can be produced for $\$ 4.3-\$ 9.2 /$ gal (equivalent to $\$ 3.8$ $\$ 8.1 /$ GGE in 2011 US dollars) [112, 113], which is expected to decrease once the technology can be further improved. STJ fuel through DSH process was evaluated to be \$7.2/gal (equivalent to \$6.3/GGE in 2011 US dollars) [113] and this can be reduced when the technology and market are further developed. As seen in Table 8, the production costs from intermediates to final products increase slightly for HRJ process and increase significantly for DSH process. The credits obtained from the co-products in the HRJ 
process lowers the cost of the upgrading processes from intermediates to jet fuel and benefits the entire conversion process. The cost estimates for the other upgrading processes are not available and require future investigation.

The GHG emissions of jet fuels from the reviewed pathways are compared in Figure 9, using $\mathrm{gCO}_{2} / \mathrm{MJ}$ basis. The GHG emission of ATJ pathway is currently not available, so only the data for process to make alcohols is reported here. A potential penalty, expected for upgrading alcohols to jet fuels, is roughly estimated based on the environmental impact of the refinery processes, including dehydration, oligomerization and hydro-treating. It is presented as a dashed line box, shown in Figure 9. GHG emissions primarily come from the farm input, land use change, and biorefinery processes. The GHG emissions from HRJ pathways range from $16 \%$ to $800 \%$ of those from conventional jet fuel depending on the feedstocks as well as coproducts [3]. For F-T BTL, the life-cycle GHG emissions are -2-12.2 $\mathrm{gCO}_{2} \mathrm{e} / \mathrm{MJ}$ from the use of corn stover, forest residue, and switchgrass, approximately $-2 \%-14 \%$ of those of conventional jet fuel [3]. The STJ process through the direct sugar-to-hydrocarbons process contributes $15 \mathrm{gCO}_{2} \mathrm{e} / \mathrm{MJ}$ GHG emissions [43], about an $82 \%$ reduction from conventional jet fuel. Apparently the GHG emissions are reduced when using the bio-jet fuel and STJ pathway has the highest reduction. 
Table 6. Production Yields from Various Biomass Feedstocks Using Various Pathways

\begin{tabular}{|c|c|c|c|c|c|}
\hline & Pathway & Biomass & $\begin{array}{c}\text { Intermediate } \\
\text { Yield } \\
\text { [GGE/BDT] }\end{array}$ & $\begin{array}{c}\text { Jet Fuel }^{\mathrm{A}} \text { Yield } \\
\text { [gal/BDT]/ } \\
\text { [GGE/BDT] }\end{array}$ & Ref. \\
\hline \multirow{26}{*}{$\frac{\stackrel{0}{\frac{0}{0}}}{\frac{8}{0}}$} & \multirow{4}{*}{ Ethanol to Jet } & Dry Mill & --- & --- & \multirow{4}{*}{$\begin{array}{c}{[38,61,63} \\
64,71,83, \\
85,177, \\
178]\end{array}$} \\
\hline & & Corn $^{\mathrm{Q}}$ & 77.5 & $39.6 / 44.7$ & \\
\hline & & Unrefined Sugar $^{\mathrm{Q}}$ & 13.9 & $7.1 / 8.0$ & \\
\hline & & Switchgrass ${ }^{Q}$ & 55.9 & $28.5 / 32.2$ & \\
\hline & \multirow{9}{*}{$\begin{array}{c}\text { N-butanol to Jet } \\
\text { (Dehydrated over a Pd/C- } \\
\mathrm{K}_{3} \mathrm{PO}_{4} \text { catalyst) }\end{array}$} & Corn Stover ${ }^{R}$ & 120.9 & $74.1 / 83.7$ & \multirow{9}{*}{$\begin{array}{c}{[73,179-} \\
185]\end{array}$} \\
\hline & & Corn Fiber ${ }^{\mathrm{R}}$ & 57.2 & $34.2 / 38.6$ & \\
\hline & & Glucose $^{\mathrm{R}}$ & 112.7 & $69.0 / 78$ & \\
\hline & & Wheat Straw $^{\mathrm{R}}$ & 112.7 & $69.0 / 78$ & \\
\hline & & Liquefied Corn Starch $^{\mathrm{R}}$ & 112.7 & $69.0 / 78$ & \\
\hline & & Switchgrass $^{\mathrm{R}}$ & 101.6 & $62.3 / 70.4$ & \\
\hline & & Barlev Straw ${ }^{\mathrm{R}}$ & 118.1 & $72.4 / 81.8$ & \\
\hline & & Sweet Potato Slurrv ${ }^{R}$ & 53.5 & $32.8 / 37.1$ & \\
\hline & & Whev Permeate ${ }^{\mathrm{R}}$ & 120.9 & $74.1 / 83.7$ & \\
\hline & \multirow{8}{*}{$\begin{array}{c}\text { N-Butanol to Jet } \\
\text { (Oliomerization Reaction) }\end{array}$} & Corn Fiber ${ }^{\mathrm{R}}$ & 57.2 & $10.0 / 11.3$ & \multirow{8}{*}{$\begin{array}{l}{[38,68,71} \\
72,80,179- \\
185]\end{array}$} \\
\hline & & Glucose $^{\mathrm{R}}$ & 112.7 & $19.5 / 22$ & \\
\hline & & Wheat Straw ${ }^{\mathrm{R}}$ & 112.7 & $19.5 / 22$ & \\
\hline & & Liquefied Corn Starch ${ }^{\mathrm{R}}$ & 112.7 & $19.5 / 22$ & \\
\hline & & Switchgrass ${ }^{\mathrm{R}}$ & 101.6 & $17.6 / 19.9$ & \\
\hline & & $\begin{array}{l}\text { Corn Stover }^{R} \\
\text { Barlev Straw }\end{array}$ & $\begin{array}{l}120.9 \\
118.1\end{array}$ & $\frac{21.0 / 23.7}{205 / 232}$ & \\
\hline & & Sweet Potato $^{R}$ & 53.5 & $9.3 / 10.5$ & \\
\hline & & Whey Permeate $^{\mathrm{R}}$ & 120.9 & $21.0 / 23.7$ & \\
\hline & \multirow{4}{*}{ Isobutanol to Jet } & Dry Mill & --- & --- & \multirow{4}{*}{$\begin{array}{l}{[38,68,71,} \\
72,77,92, \\
133,178, \\
181]\end{array}$} \\
\hline & & Corn $^{\mathrm{S}}$ & 163.6 & $51.9 / 58.6$ & \\
\hline & & Unrefined Sugarcane $^{S}$ & 29.4 & $9.3 / 10.5$ & \\
\hline & & Switchgrass ${ }^{\mathrm{S}}$ & 118.4 & $14.4 / 16.3$ & \\
\hline & Methanol to Jet & Woody Biomass $^{\mathrm{T}}$ & 79.2 & $45.4 / 51.3$ & $\begin{array}{c}{[83,186-} \\
189]\end{array}$ \\
\hline \multirow{20}{*}{ 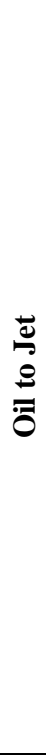 } & \multirow{9}{*}{ HRJ } & Vegatable Oil & --- & --- & \multirow{9}{*}{$\begin{array}{c}{[3,21,100,} \\
190-199]\end{array}$} \\
\hline & & Palm Seed $^{\mathrm{E}, \mathrm{U}}(22 \%$ Oil) & 58.3 & $41.9 / 47.3$ & \\
\hline & & Rapeseed $^{\mathrm{E}, \mathrm{U}}(45 \%$ Oil) & 127.9 & $75.2 / 85$ & \\
\hline & & Soybean $^{\mathrm{E}, \mathrm{U}}(18 \%$ Oil $)$ & 49.8 & $29.9 / 33.8$ & \\
\hline & & Jatronha Seed ${ }^{\mathrm{E}, \mathrm{U}}(35 \%$ Oil) & 92.0 & $59.9 / 67.7$ & \\
\hline & & Camelina Seed ${ }^{\mathrm{E}, \mathrm{U}}(29 \%$ Oil) & 85.9 & $47.2 / 53.3$ & \\
\hline & & Camelina Seed $^{\mathrm{E}, \mathrm{U}}(41 \%$ Oil) & 121.4 & $66.2 / 74.8$ & \\
\hline & & $\operatorname{Algal}^{\mathrm{E}, \mathrm{U}}(25 \%$ Oil $)$ & 61.9 & $44.3 / 50$ & \\
\hline & & Salicornia Seed ${ }^{\mathrm{E}, \mathrm{U}}(28.2 \%$ Oil $)$ & 61.6 & $45.0 / 50.8$ & \\
\hline & \multirow{3}{*}{$\mathrm{CH}$} & Soybean (18\% Oil) & 28.7 & $7.6^{\mathrm{B}} / 8.6$ & \multirow{3}{*}{$\begin{array}{c}{[3,107,} \\
200]\end{array}$} \\
\hline & & Jatropha Seed (35\% Oil) & 56.0 & $8.9^{\mathrm{B}} / 10.1$ & \\
\hline & & Tung Seed (40.4\% Oil) & 102.1 & $15.2^{\mathrm{B}} / 17.2$ & \\
\hline & \multirow{8}{*}{ HDCJ } & Dry Wood ${ }^{\mathrm{V}}$ & 93.5 & $41.1^{\mathrm{B}} / 46.4$ & \multirow{8}{*}{ [201-209] } \\
\hline & & Corn Stover ${ }^{V}$ & 71.8 & $36.4^{\mathrm{B}} / 41.1$ & \\
\hline & & Switchgrass ${ }^{V}$ & 74.8 & $37.9^{\mathrm{B}} / 42.8$ & \\
\hline & & Sugarcane Bagasse $^{V}$ & 62.3 & $31.6^{\mathrm{B}} / 35.7$ & \\
\hline & & Algae $18 \%$ Oil Content ${ }^{\mathrm{V}}$ & 22.5 & $11.4^{\mathrm{B}} / 12.9$ & \\
\hline & & Algae $24 \%$ Oil Content ${ }^{V}$ & 29.9 & $15.2^{\mathrm{B}} / 17.2$ & \\
\hline & & Forest Residue Low & 74.8 & $37.9^{\mathrm{B}} / 42.8$ & \\
\hline & & Forest Residue High & 81.1 & $41.1^{\mathrm{B}} / 46.4$ & \\
\hline
\end{tabular}




\begin{tabular}{|c|c|c|c|c|c|}
\hline & Pathway & Biomass & $\begin{array}{c}\text { Intermediate } \\
\text { Yield } \\
\text { [GGE/BDT] }\end{array}$ & $\begin{array}{c}\text { Jet Fuel }^{\mathbf{A}} \text { Yield } \\
{[\mathrm{gal} / \mathrm{BDT}] /[\text { GGE/BDT] }}\end{array}$ & Ref. \\
\hline \multirow{15}{*}{ 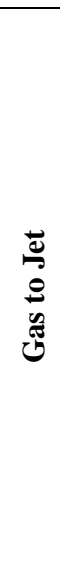 } & \multirow{4}{*}{ F-T to Jet } & Natural Gas & -- & $156.4 / 176.7$ & \multirow{4}{*}{$\begin{array}{c}{[3,55,131,210} \\
215]\end{array}$} \\
\hline & & $\mathrm{Coal}^{\mathrm{J}}$ & --- & $84.1^{\mathrm{H}} / 95$ & \\
\hline & & Hardwood $^{\mathrm{I}}$ & --- & $63.9 / 72.2$ & \\
\hline & & Switchgrass & --- & --- & \\
\hline & \multirow{11}{*}{ Gas Fermentation } & Natural Gas ${ }^{\mathrm{O}, \mathrm{Q}}$ & 306.8 & $139.5^{\mathrm{C}} / 157.6$ & \multirow{11}{*}{$\begin{array}{l}{[38,61,63,64,} \\
68,71,72,77, \\
133,143,145, \\
146,177,178, \\
181,216-218]\end{array}$} \\
\hline & & & & $204.5^{\mathrm{D}} / 231$ & \\
\hline & & Natural Gas ${ }^{P, Q}$ & 259.1 & $117.8^{\mathrm{C}} / 133.1$ & \\
\hline & & & & $172.7^{\mathrm{D}} / 195.1$ & \\
\hline & & Biomass $^{\mathrm{Q}}$ & 65.8 & $29.9^{\mathrm{C}} / 33.8$ & \\
\hline & & Hardwood $^{\mathrm{Q}}$ & 77.3 & $\frac{43.8^{\mathrm{D}} / 39.8}{35.2^{\mathrm{C}} / 39.8}$ & \\
\hline & & & & $51.5^{\mathrm{D}} / 58.2$ & \\
\hline & & Biomass Feedstock $^{\mathrm{Q}}$ & 52.7 & $23.9^{\mathrm{C}} / 27$ & \\
\hline & & & & $35.1^{\mathrm{D} / 39.7}$ & \\
\hline & & Biomass Feedstock $^{\mathrm{Q}}$ & 46.8 & $21.3^{\mathrm{C}} / 24.1$ & \\
\hline & & & & $312^{\mathrm{D}} / 35.2$ & \\
\hline \multirow{9}{*}{ 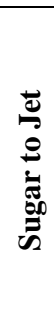 } & \multirow{7}{*}{ Catalytic Upgrading } & Corn Stover ${ }^{\mathrm{F}, \mathrm{W}}$ & 91.8 & $52.7 / 59.5$ & \multirow{5}{*}[162,219-222]{} \\
\hline & & Sugarcane Bagasse & 62.8 & $49.0 / 55.4$ & \\
\hline & & Hardwood & 75.3 & $41.7 / 47.1$ & \\
\hline & & Switchgrass ${ }^{F, W}$ & 81.5 & $48.1 / 54.3$ & \\
\hline & & Sugarcane ${ }^{F, X}$ & 65.8 & $44.5 / 50.3$ & \\
\hline & & $\begin{array}{c}\text { Sugar Beet }{ }^{\mathrm{F}, \mathrm{X}} \\
\text { Cellulosic Mass }^{\mathrm{K}, \mathrm{Y}}\end{array}$ & $\frac{54.8}{26.9}$ & $37.1 / 41.9$ & {$[81,175]$} \\
\hline & & Corn Stover, $\mathrm{W}$ & 91.8 & $\frac{1.0 / 12.0}{21.9 / 24.7}$ & {$[162,223]$} \\
\hline & \multirow[t]{2}{*}{ Direct Sugar to Jet } & Corn Stover ${ }^{\mathrm{M}, \mathrm{W}}$ & 91.8 & $36.9 / 41.7$ & \multirow{2}{*}[172,220]{} \\
\hline & & Corn Stover $^{N, Z}$ & 56.4 & $18.5 / 20.9$ & \\
\hline
\end{tabular}

Notes: ${ }^{\mathrm{A}}$ Unless otherwise stated "Jet Fuel" is defined as $\mathrm{C}_{9}-\mathrm{C}_{15}$ n-alkanes

${ }^{B}$ Jet range based off of boiling point

${ }^{\mathrm{C}}$ Using Ethanol to Jet Pathway to create Jet Fuel $\mathrm{C}_{9}-\mathrm{C}_{15}$ alkanes

${ }^{\mathrm{D}}$ Using Isobutanol to Jet Pathway, Jet Fuel $\mathrm{C}_{9}-\mathrm{C}_{15}$ alkanes

${ }^{\mathrm{E}}$ Uses the decarboxylation pathway

${ }^{\mathrm{F}}$ Catalytic Upgrading Using Virent Pathway

${ }^{\mathrm{H}}$ Coal to Liquid Fuel (CTL), unknown ranges of gasoline, diesel, and jet

I The average of several design cases for hardwood gasification

${ }^{\mathrm{J}}$ The average of six notable sources for the production of CTL fuel from coal

${ }^{\mathrm{K}}$ Catalytic Upgrading Condensation to HMF to Jet

${ }^{\mathrm{L}}$ Catalytic Upgrading non-fermentation of biomass

${ }^{\mathrm{M}}$ Direct Sugar to Jet Mevalonic (MVA) Pathway

${ }^{N}$ Direct Sugar to Jet Deoxysylulose-5-phosphate (DXP) Pathway

o $90 \%$ of Carbon Conversion to Syngas

$\mathrm{P} 76 \%$ of Carbon Conversion to Syngas

${ }^{\mathrm{Q}}$ Starting Intermediate: Ethanol

${ }^{\mathrm{R}}$ Starting Intermediate: A:B:E (Acetone:Butanol:Ethanol)

${ }^{\mathrm{S}}$ Starting Intermediate: Ethanol $\rightarrow$ Isobutanol

${ }^{\mathrm{T}}$ Starting Intermediate: Methanol

${ }^{U}$ Starting Intermediate: Triglyceride Oil

${ }^{v}$ Starting Intermediate: Liquid Pyrolysis Oil

${ }^{\mathrm{w}}$ Starting Intermediate: Glucose : Xylose

${ }^{x}$ Starting Intermediate: Sucrose

${ }^{Y}$ Starting Intermediate: Fructose

${ }^{\mathrm{z}}$ Starting Intermediate: Glucose : Xylose : Fructose

--- Data not available 
Table 7. Lower Heating Values of the Intermediates

\begin{tabular}{lcl}
\hline \multicolumn{1}{c}{ Lower Heating Value } & MMBTU/gal & Ref. \\
\hline Gasoline heating value & 0.12 & {$[83]$} \\
Ethanol heating value & 0.08 & {$[83]$} \\
Acetone heating value & 0.08 & {$[224]$} \\
n-butanol heating value & 0.10 & {$[95]$} \\
Isobutanol heating value & 0.10 & {$[92]$} \\
Methanol heating value & 0.06 & {$[224]$} \\
Palm oil heating value & 0.12 & {$[225]$} \\
Rapeseed oil heating value & 0.13 & {$[225]$} \\
Soybean oil heating value & 0.13 & {$[225]$} \\
Jatropha oil heating value & 0.12 & {$[226]$} \\
Camelina oil heating value & 0.14 & {$[227]$} \\
Algal oil heating value & 0.12 & {$[228]$} \\
Salicornia oil heating value & 0.12 & {$[3]$} \\
Tung oil heating value & 0.12 & {$[229]$} \\
Pyrolysis oil heating value & 0.07 & {$[230]$} \\
Glucose heating value & 0.09 & {$[231]$} \\
Xylose heating value & 0.08 & {$[83]$} \\
Sucrose heating value & 0.09 & {$[83]$} \\
Fructose heating value & 0.09 & {$[232]$} \\
Jet fuel heating value & 0.13 & {$[20]$} \\
\hline
\end{tabular}


Table 8. Production costs of Jet Fuel from Various Pathways

\begin{tabular}{|c|c|c|c|c|c|}
\hline Category & Pathways & Intermediate & 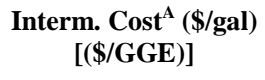 & $\begin{array}{c}\text { Final jet fuel cost }(\$ / \text { gal }) \\
{[((\$ / G G E)]}\end{array}$ & Ref. \\
\hline \multirow{4}{*}{ ATJ } & Ethanol to Jet & Ethanol $^{\mathrm{B}}$ & $2.5-2.6(3.8-4.0)$ & \multirow{4}{*}{ Not Available } & {$[83,85]$} \\
\hline & n-Butanol to Jet & $\mathrm{N}^{-b}$ & $3.7(4.1)$ & & [92] \\
\hline & Iso-Butanol to Jet & Isobutanol $^{\mathrm{B}}$ & $3.6(4.0)$ & & [92] \\
\hline & Methanol to Jet & Methanol & $1.5(3.0)$ & & [233] \\
\hline \multirow{3}{*}{ OTJ } & HRJ & Bio-Oil $^{\mathrm{C}}$ & $4.3-8.5(4.0-8.2)$ & $4.3-9.2(4.0-8.5)$ & $\begin{array}{c}{[100,112,113,} \\
234]\end{array}$ \\
\hline & $\mathrm{CH}$ & Bio-Oil $^{\mathrm{D}}$ & $1.7-4.3(1.6-3.9)$ & \multirow{2}{*}{ Not Available } & {$[113,235]$} \\
\hline & HDCJ & Pyrolysis Oil & $1.0-1.5(1.8-2.6)$ & & {$[118,201,236]$} \\
\hline \multirow{2}{*}{ GTJ } & F-T to Jet (BTL) & $\begin{array}{c}\text { Syngas derived } \\
\text { diesel }\end{array}$ & $6.4-6.7(6.0-6.2)$ & \multirow{2}{*}{ Not Available } & [56] \\
\hline & Gas Fermentation & $\begin{array}{c}\text { Ethanol from } \\
\text { syngas fermentation }\end{array}$ & $2.8-3.1(4.3-4.8)$ & & {$[237,238]$} \\
\hline \multirow[t]{2}{*}{ STJ } & \begin{tabular}{|c|} 
Catalytic \\
Upgrading of Sugar \\
to Jet
\end{tabular} & $\mathrm{HMF}$ and DMF & $6.2-9.4(4.8-9.9)$ & Not Available & {$[175]$} \\
\hline & DSH & Hydrocarbons ${ }^{\mathrm{E}}$ & $4.6^{\mathrm{F}}(4.4)$ & $7.2(6.6)$ & {$[113,239]$} \\
\hline
\end{tabular}

Note: ${ }^{A}$ The cost numbers are inflated to 2011 U.S. dollars using the industrial inorganic Chemical Index for SRI Consulting [240]

${ }^{\mathrm{B}}$ The alcohol intermediates are produced from cellulosic biomass

${ }^{\mathrm{C}}$ Soybean and algal oils are selected for the lower and higher end bio-oils

D Jatropha and soybean oils are selected for the lower and higher end bio-oils

E Pentadecane

${ }^{\mathrm{F}}$ Target value of the product

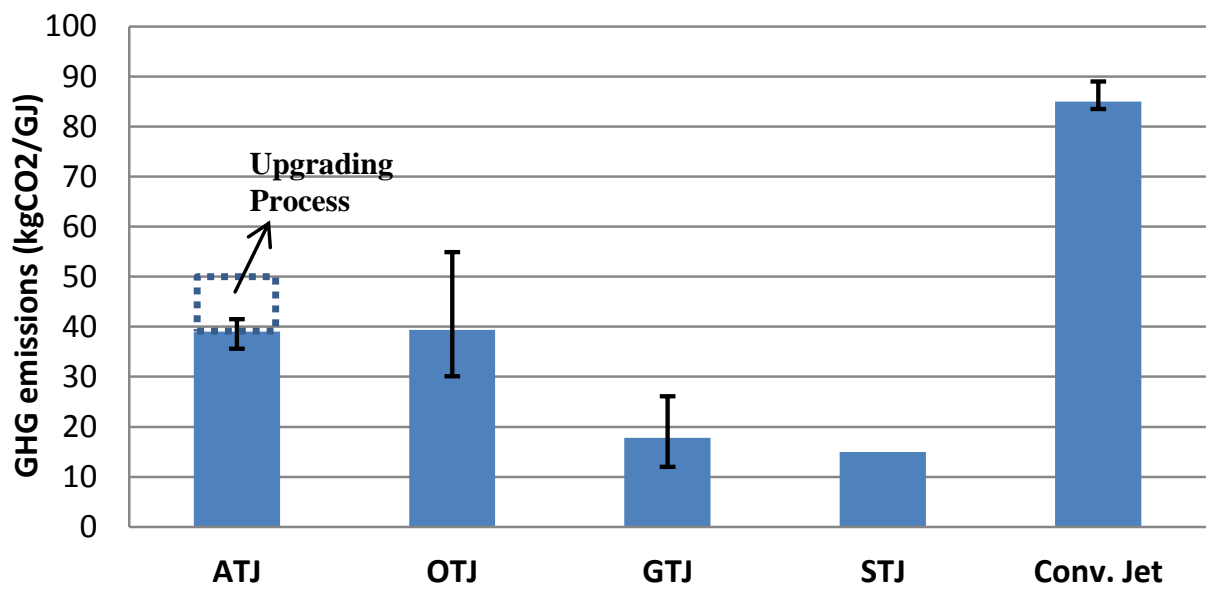

Fig. 9. GHG emissions of jet fuel from various pathways

$([3,12,14,21,33,43,55-57,92,127,128,199,241-243])$

Note: ${ }^{A}$ For ATJ pathway, the higher and lower end uncertainties represents GHG emissions of n-butanol and ethanol, respectively

${ }^{\mathrm{B}}$ For OTJ pathway, the higher and lower end uncertainties represents GHG emissions of rapeseed and palm oils, respectively

${ }^{\text {C }}$ For the GHG emissions of OTJ and GTJ pathways, without land use change is considered

${ }^{\mathrm{D}}$ For GTJ pathways, switchgrass is selected as the feedstock; without soil carbon sequestration is considered 


\section{Conclusion}

The issues of jet fuel cost, energy supply, energy security, and aviation emissions have driven the development of aircraft and engine technologies throughout the history of flight. Sustainable biomassderived bio-jet fuel represents a major opportunity to resolve these issues. Many conversion technologies that turn biomass into jet fuels have been developed, and some of them are commercially viable. In this review, most of the current technologies have been classified into four major categories: ATJ, OTJ, GTJ, and STJ. Each category has been described and reviewed with regard to feedstocks, upgrading processes, production costs when available, sustainability, and commercial readiness.

Sustainable bio-jet fuel not only brings environmental benefits for aviation, but helps the development of a new industry. There is still a considerable way to proceed before renewable aviation fuels become economically viable. Through the combination of expertise of the aviation industry, government, biofuel companies, agriculture organizations, and academic systems, along with encouragement from regional banks, progress is being made toward an optimal process that utilizes the most effective feedstock sources, is amenable with current infrastructure, and produces renewable aviation fuels.

\section{Acknowledgement}

The work was sponsored by the Research Center for Energy Technology and Strategy, National Cheng Kung University and also supported by the U.S. Department of Energy, Bioenergy Technologies Office., under Contract No. DE-AC36-08GO28308 with the National Renewable Energy Laboratory.

\section{Reference}

[1] US Energy Information Administration. What Fuels Are Made from Crude Oil? 2013.

[2] Air Transportation Action Group. Beginner's Guide to Aviation Biofuels. 2009.

[3] Stratton RW, Wong HM, Hileman JI. Life Cycle Greenhouse Gas Emissions from Alternative Jet Fuels. PARTNER (Partnership for Air Transportation Noise and Emissions Reduction); 2010.

[4] IEA. The Potential Role of Biofuels in Commercial Air Transport - BioJetFuel. In: 40 IBT, editor.2012.

[5] Leuphana. Bio Aviation Fuel Feedstock Supply-Challengs, Strategies and Recent Developments. ICAO Aviation and Sustainable Alternative Fuels Workshop. Montreal2011.

[6] Airlines for America. Airline Energy Q\&A 2013.

[7] Duly A, Harris J, Khatchadourian A, Ulics R, Wolter M. Price and expenditure measures of petroleum products: a comparison. Monly Labor Review2006.

[8] Research and Innovative Technology Administration, Bureau of Transportation Statustics. Airline Fuel Cost and Consumption. 2013.

[9] Caldecott B, Tooze S. Green skies thinking: promoting the development and commercialisation of sustainable bio-jet fuels. 2009.

[10] Gnansounou E, Dauriat A. Techno-economic analysis of lignocellulosic ethanol: A review. Bioresource Technol. 2010;101:4980-91.

[11] Rosillo-Calle F, Thrän D, Seiffert M, Teelucksingh S. THE POTENTIAL ROLE OF BIOFUELS IN COMMERCIAL AIR TRANSPORT - BIOJETFUEL. IEA Bioenergy; 2012.

[12] Bauen A, Howes J, Bertuccioli L, Chudziak C. Review of the potential for biofuels in aviation. E4tech; 2009.

[13] Hileman J. Carbon Neutral Aviation Growth through Alternative Fuels. GROUP ON INTERNATIONAL AVIATION AND CLIMATE CHANGE (GIACC) FOURTH MEETING. Montréal, Canada2009.

[14] Skone TJ, Gerdes K. Development of Baseline Data and Analysis fo Life Cycle Greenhouse Gas Emissions of Petroleum-Based Fuels. National Energy Technology Laboratory,; 2008. 
[15] Hileman J, Wong HM, D. Ortiz, Brown N, Maurice L, Rumizen M. The Feasibility and Potential Environmental Benefits of Alternative Fuels for Commercial Aviation. 26th International Congress of the Aeronautical Sciences. Anchorage Alaska2008.

[16] Air Transport Action Group. Powering The Future of Flight. Air Transport Action Group; 2012.

[17] Department of Energy. Conversion Technologies for Advanced Biofuels. Department of Energy, Office of the Biomass Program in the Office of Energy Efficiency and Renewable Energy, Conversion Technologies for Advanced Biofuels Workshop; 2011.

[18] Bender M. Economic feasibility review for community-scale farmer cooperatives for biodiesel. Bioresource Technol. 1999;70:81-7.

[19] U.S. Department of Defense. DETAIL SPECIFICATION: TURBINE FUEL, AVIATION, KEROSENE TYPE, JP-8 (NATO F-34), NATO F-35, and JP-8+100 (NATO F-37) 2011.

[20] American Society for Testing and Materials. ASTM 1655-08a: Standard Specification for Aviation Turbine Fuels. 2013.

[21] Agusdinata DB, Zhao F, Ileleji K, DeLaurentis D. Life Cycle Assessment of Potential Biojet Fuel Production in the United States. Environ Sci Technol. 2011;45:9133-43.

[22] ONGC, Quality Control Laboratory. SPECIFICATION FOR AVIATION TURBINE FUEL (Jet A1) Def Stan 91-91 issue 6 Amendment 1 (UK). 2008.

[23] American Society for Testing and Materials. ASTM D7566 - 12a Standard Specification for Aviation Turbine Fuel Containing Synthesized Hydrocarbons. 2013.

[24] Exxonmobil Aviation. World Jet Fuel Specifications. 2005.

[25] ASTM International. ASTM D975 - 12a Standard Specification for Diesel Fuel Oils. 2013.

[26] UK Ministry of Defence. Defence Standard 91-91, Turbine Fuel, Aviation Kerosine Type, Jet A1. 2013.

[27] Viljoen CL, Ajam M. FULLY SYNTHETIC JET FUEL. US: SASOL TECHNOLOGY 2012.

[28] De Klerk A. FISCHER-TROPSCH JET FUEL PROCESS US2010.

[29] Zheng YN, Li LZ, Xian M, Ma YJ, Yang JM, Xu X, et al. Problems with the microbial production of butanol. J Ind Microbiol Biotechnol. 2009;36:1127-38.

[30] UOP LLC. Green Jet Fuel 2010.

[31] Neste Oil. NExBTL aviation fuel. 2011.

[32] Kalnes TN, Mccall MM, Shonnard DR. Renewable Diesel and Jet-Fuel Production from Fats and Oils. In: Crocker M, editor. Thermochemical Conversion of Biomass to Liquid Fuels and Chemicals: Royal Society of Chemistry; 2010.

[33] Shonnard DR, Williams L, Kalnes TN. Camelina-derived jet fuel and diesel: Sustainable advanced biofuels. Environmental Progress \& Sustainable Energy. 2010;29:382-92.

[34] EcoSeed. U.S. Air Force completes Alcohol-to-Jet fuel test flight. 2012.

[35] BYOGY Renewables. Alcohol To Jet (ATJ) Emerging Through ASTM. ICAO Aviation And Sustainable Alternative Fuels Workshop. Montreal Canada2011.

[36] Gevo. Gevo Awarded \$5 Million to Develop Cellulosic Jet Fuel Grant will focus on developing sustainable, cost-effective biojet fuel from woody biomass 2011.

[37] Syn Fuels International Inc. SYNFUELS EEEJet TECHNOLOGY. 2013.

[38] Wright ME, Harvey BG, Quintana RL. Highly efficient zirconium-catalyzed batch conversion of 1-butene: A new route to jet fuels. Energ Fuel. 2008;22:3299-302.

[39] Department of Energy, Energy Efficiency \& Renewable Energy, Biomass Technologies Office. Fermentation of Sugars to Hydrocarbons. Department of Energy2012.

[40] Department of Energy, Energy Efficiency \& Renewable Energy, Biomass Technologies Office. Catalytic Conversion of Sugars to Conventional Liquid Fuels. Department of Energy2012.

[41] Total, Amyris. Breaking the Barriers with Breakthrough Jet Fuel Solutions. Berlin Airshow. Berlin2012.

[42] Bauldreay JM. Technologies of fuel conversion. AIREG Workshop. Berlin, Germany2012.

[43] Nassar A, Granco G, Seabra J, Harfuch L, Moreira M, Moura P. Sustainability of sugarcanederived renewable jet fuel: life cycle GHG emissions and benchmark of major sustainability standards. ICONE; 2012. 
[44] Virent. Exceptional Jet Fuel Produced From High-Quality Cellulosic Sugars. 2012.

[45] Newsmax. Boeing, Embraer Back Sugar Jet-Fuel Study. 2011.

[46] Knovel. Engineers transform sugars into jet fuel 2012.

[47] Arstechnica. Combined bacterial/metal catalysis turns sugars to jet fuel. 2012.

[48] Blommel PG, Keenan GR, Rozmiarek RT, Cortright RD. Catalytic conversion of sugar into conventional gasoline, diesel, jet fuel, and other hydrocarbons. International sugar journal. 2008;110.

[49] Biodiesel Magazine. Aemetis expands biojet license agreement with Chevron LG. 2012.

[50] Applied Research Associate. Benefits of producing Next Generation Renewable Drop-in Fuels using our Biofuel ISOCONVERSION Process. 2011. 2012.

[51] Applied Research Associate Inc. A novel process to convert oils from plants and algae into fuel.

[52] Elgowainy A, Han J, Wang M, Hileman J, Carter N. Development of Life-Cycle Analysis Module of Aviation Fuel/Aircraft Systems in GREET. GREET Training Workshop. Washington D.C.2012.

[53] Whitman T, Yanni S, Whalen J. Life cycle assessment of corn stover production for cellulosic ethanol in Quebec. Canadian Journal of Soil Science. 2011;91:997-1012.

[54] European Biofuels Technology Platform. Biofuels for Air Travel. 2012.

[55] International Air Transport Association. IATA 2010 Report on Alternative Fuels. 5th edition ed: International Air Transport Association; 2010.

[56] Hileman JI, Ortiz DS, Bartis JT, Wong HM, Donohoo PE, Weiss MA, et al. Near-Term Feasibility of Alternative Jet Fuels. RAND Corporation; 2009.

[57] Rye L, Blakey S, Wilson CW. Sustainability of supply or the planet: a review of potential drop-in alternative aviation fuels. Energy \& Environmental Science. 2010;3:17-27.

[58] International Civil Aviation Organization. MAIN SUMMARY OF ACCOMPLISHMENTS AND PROJECTED ACTIVITIES ON SUSTAINABLE ALTERNATIVE FUELS FOR AVIATION. 2012.

[59] Rutz D, Janssen R. Biofuel Technology Handbook. Munchen, Germany: WIP Renewable Energies; 2007.

[60] Howk BW, Lazier WA. The hydration, dehydration and hydrolysis of Organic Compounds. In: National Research Council, editor. Twelfth report of the committee on catalysis. New York, NY: John Wiley \& Sons, Inc; 1940. p. 28-69.

[61] Zhan N, Hu Y, Li H, Yu D, Han Y, Huang H. Lanthanum-phosphorous modified HZSM-5 catalysts in dehydration of ethanol to ethylene: A comparative analysis. Catalysis Communications. 2010;11:633-7.

[62] Hu Y, Zhan N, Dou C, Huang H, Han Y, Yu D, et al. Selective dehydration of bio-ethanol to ethylene catalyzed by lanthanum-phosphorous-modified HZSM-5: Influence of the fusel. Biotechnology Journal. 2010;5:1186-91.

[63] Weissermel K, Arpe HJ. Industrial Organic Chemistry. 3rd ed. New York, NY: John Wiley \& Sons; 2008.

[64] S. Aldrett JHW. Improved Ethylene Oligomerization Modeling using Aspentech's Polymers Plus AlChE 2003 Annual Meeting. San Francisco, CA2003.

[65] Richard EP. The selective oligomerization of ethylene using chromium diphosphine catalysts and the synthesis and reactivity of Group 7 carbonyl derivatives relevant to synthesis gas conversion [dissertation]: California Institute of Technology; 2009.

[66] Peters MW, Taylor JD. Renewable Jet Fuel Blendstock From Isobutanol. US2011.

[67] Gruber PR, Peters MW, Griffith JM, Obaidi YA, Manzer LE, Taylor JD, et al. Renewable Compositions. US2012.

[68] Wright M. PROCESS FOR THE DEHYDRATION OF AQUEOUS BIO-DERIVED TERMINAL ALCOHOLS TO TERMINAL ALKENES. US2012.

[69] Wright M. Biomass to Alcohol to Jet/Diesel. NAVAIR2012.

[70] Wright ME, Harvey BG, Quintana RL. Diesel and Jet Fuels Based on the Oligomerization of Butene. US2012.

[71] B G Harvey MEW. Selective Isomerization and Oligomerization of Olefin Feedstocks for the Production of Turbine and Diesel Fuels. US2011. 
[72] Harvey BG, Quintana RL. Synthesis of renewable jet and diesel fuels from 2-ethyl-1-hexene. Energy \& Environmental Science. 2010;3:352-7.

[73] Anbarasan P, Baer ZC, Sreekumar S, Gross E, Binder JB, Blanch HW, et al. Integration of chemical catalysis with extractive fermentation to produce fuels. Nature. 2012;491:235-9.

[74] Taylor J, Jenni M, Peters M. Dehydration of Fermented Isobutanol for the Production of Renewable Chemicals and Fuels. Top Catal. 2010;53:1224-30.

[75] Armstrong PA, Bhatt B, Heydorn EC, Toseland BA. Isobutanol Dehydration: A key step in producing MTBEE from Syngas. Air Products and Chemicals, Inc.; 1993.

[76] Bond JQ, Alonso DM, Wang D, West RM, Dumesic JA. Integrated Catalytic Conversion of $\gamma$ Valerolactone to Liquid Alkenes for Transportation Fuels. Science. 2010;327:1110-4.

[77] Yoon JW, Chang J-S, Lee H-D, Kim T-J, Jhung SH. Trimerization of isobutene over cation exchange resins: Effect of physical properties of the resins and reaction conditions. Journal of Molecular Catalysis A: Chemical. 2006;260:181-6.

[78] Baliban RC, Elia JA, Floudas CA, Xiao X, Zhang Z, Li J, et al. Thermochemical Conversion of Duckweed Biomass to Gasoline, Diesel, and Jet Fuel: Process Synthesis and Global Optimization. Industrial \& Engineering Chemistry Research. 2013.

[79] Ipatieff VN, Corson BB, Egloff G. Polymerization, a New Source of Gasoline. Industrial \& Engineering Chemistry. 1935;27:1077-81.

[80] Lu M, Xiong G, Zhao H, Cui W, Gu J, Bauser H. Dehydration of 1-butanol over $\gamma$-A12O3 catalytic membrane. Catalysis Today. 1995;25:339-44.

[81] Chheda JN, Dumesic JA. An overview of dehydration, aldol-condensation and hydrogenation processes for production of liquid alkanes from biomass-derived carbohydrates. Catalysis Today. 2007;123:59-70.

[82] Kazi FK, Fortman J, Anex R, Kothandaraman G, Hsu D, Aden A, et al. Techno-Economic Analysis of Biochemical Scenarios for Production of Cellulosic Ethanol. National Renewable Energy Laboratory; 2010.

[83] Humbird D, Davis R, Tao L, kinchin C, Hsu D, Aden A, et al. Process Design and Economics for Biochemical Conversion of Lignocellulosic Biomass to Ethanol: Dilute-Acid Pretreatment and Enzymatic Hydrolysis of Corn Stover. National Renewable Energy Laboratory; 2011.

[84] Dutta A, Dowe N, Ibsen KN, Schell DJ, Aden A. An economic comparison of different fermentation configurations to convert corn stover to ethanol using Z. mobilis and Saccharomyces. Biotechnology Progress. 2010;26:64-72.

[85] Dutta A, Talmadge M, Hensley J, Worley M, Dudgeon D, Barton D, et al. Process Design and Economics for Conversion of Lignocellulosic Biomass to Ethanol, Thermaochemical Pathway by Indirect Gasification and Mixed Alcohol Synthesis. National Renewable Energy Laboratory; 2011.

[86] Phillips SD. Technoeconomic Analysis of a Lignocellulosic Biomass Indirect Gasification Process To Make Ethanol via Mixed Alcohols Synthesis. Industrial \& Engineering Chemistry Research. 2007;46:8887-97.

[87] K-Marcuschamer D, Simmons BA, Blanch HW. Techno-economic analysis of a lignocellulosic ethanol biorefinery with ionic liquid pre-treatment. Biofuels, Bioproducts and Biorefining. 2011;5:562-9.

[88] Zhu Y, Jones S. Techno-economic Analysis for the Thermochemical Conversion of Lignocellulosic Biomass to Ethanol via Acetic Acid Synthesis. Pacific Northwest National Laboratory; 2009.

[89] Vicari K, Tallam S, Shatova T, Joo K, Scarlata C, Humbird D, et al. Uncertainty in technoeconomic estimates of cellulosic ethanol production due to experimental measurement uncertainty. Biotechnology for Biofuels. 2012;5:23.

[90] Dutta A, Bain RL, Biddy MJ. Techno-economics of the production of mixed alcohols from lignocellulosic biomass via high-temperature gasification. Environmental Progress \& Sustainable Energy. 2010;29:163-74.

[91] Qureshi N, Blaschek HP. ABE production from corn: a recent economic evaluation. J Ind Microbiol Biotechnol. 2001;27:292-7. 
[92] Tao L, Aden A, Tan ECD, Zhang M, He X, McCormick R, et al. Techno-economic Analysis and Life-cycle Assessment of Cellulosic Iso-Butanol and Comparison with Cellulosic Ethanol and n-Butanol. 2012.

[93] Kumar M, Gayen K. Developments in biobutanol production: New insights. Applied Energy. 2011;88:1999-2012.

[94] Lenz TG, Morelra AR. Economic Evaluation of the Acetone-Butanol Fermentation. Industrial \& Engineering Chemistry Product Research and Development. 1980;19:478-83.

[95] Tao L, He X, Tan ECD, Zhang M, Aden A. Techno-economic Analysis of n-Butanol from Corn Grain and Corn Stover. 2012.

[96] Wang M, Hong MW, Huo H. Life-cycle energy and greenhouse gas emission impacts of different corn ethanol plant types. Environ Res Lett. 2007;2.

[97] Kauffman N, Hayes D, Brown R. A life cycle assessment of advanced biofuel production from a hectare of corn. Fuel. 2011;90:3306-14.

[98] Wu M, Wang M, Liu J, Huo H. Assessment of potential life-cycle energy and greenhouse gas emission effects from using corn-based butanol as a transportation fuel. Biotechnology Progress. 2008;24:1204-14.

[99] Mu D, Seager T, Rao PS, Zhao F. Comparative Life Cycle Assessment of Lignocellulosic Ethanol Production: Biochemical Versus Thermochemical Conversion. Environmental Management. 2010;46:565-78.

[100] Pearlson MN. A Techno-Economic and Environmental Assessment of Hydroprocesseed Renewable Distillate Fuels [Thesis]: Massachusetts Institute of Technology 2011.

[101] Wang W-C, Thapaliya N, Campos A, Stikeleather LF, Roberts WL. Hydrocarbon fuels from vegetable oils via hydrolysis and thermo-catalytic decarboxylation. Fuel. 2012;95:622-9.

[102] Wang W-C, Turner TL, Roberts WL, Stikeleather LF. Direct injection of superheated steam for continuous hydrolysis reaction. Chemical Engineering and Processing: Process Intensification. 2012;59:52-9.

[103] Wang W-C, Turner TL, Stikeleather LF, Roberts WL. Exploration of process parameters for continuous hydrolysis of canola oil, camelina oil and algal oil. Chemical Engineering and Processing: Process Intensification. 2012;57-58:51-8.

[104] Yang F, Hanna MA, Sun R. Value-added uses for crude glycerol--a byproduct of biodiesel production. Biotechnology for Biofuels 2012;5:1-10.

[105] Gary JH, Handwerk GE, Kaiser MJ. Petroleum Refining, Technology and Economics. Boca Raton, FL: CRC Press; 2007.

[106] Park KC, Ihm SK. Comparison of Pt/zeolite catalysts for n-hexadecane hydroisomerization. Appl Catal a-Gen. 2000;203:201-9.

[107] Li L, Coppola E, Rine J, Miller JL, Walker D. Catalytic Hydrothermal Conversion of Triglycerides to Non-ester Biofuels. Energ Fuel. 2010;24:1305-15.

[108] McAfee EA. The Aemetis Biorefinery: 100\% Replacement, Renewable Jet and Diesel Fuels by Conversion of Existing Biofuels Refinery Facilities. Advanced Biofuels Marketing Conference. San Francisco2012.

[109] Lupton S. Pilot-Scale Biorefinery: Sustainable Transport Fuels from Biomass and Algal Residue via Integrated Pyrolysis and Catalytic Hydroconversion. 2013 Project Peer Review, US Department of Energy, Bioenergy Technology Office. Alexandria, VA2013.

[110] Valkenburg C. Upgrading of Biomass Fast Pyrolysis Oil (Bio-oil). 2013 Project Peer Review, US Department of Energy, Bioenergy Technology Office. Alexandria, VA2013.

[111] Zacher A, Elliott D. Bio-Oil Upgrading and Stabilization. Kansas State University Bioenergy Symposium. Manhattan, KS2011.

[112] Pearlson M, Wollersheim C, Hileman J. A techno-economic review of hydroprocessed renewable esters and fatty acids for jet fuel production. Biofuels, Bioproducts and Biorefining. 2013;7:8996. 
[113] Klein-Marcuschamer D, Turner C, Allen M, Gray P, Dietzgen RG, Gresshoff PM, et al. Technoeconomic analysis of renewable aviation fuel from microalgae, Pongamia pinnata, and sugarcane. Biofuels, Bioproducts and Biorefining. 2013;7:416-28.

[114] Zhang Y, Dube MA, McLean DD, Kates M. Biodiesel production from waste cooking oil: 2. Economic assessment and sensitivity analysis. Bioresource Technol. 2003;90:229-40.

[115] Marchetti JM, Miguel VU, Errazu AF. Techno-economic study of different alternatives for biodiesel production. Fuel Process Technol. 2008;89:740-8.

[116] Haas MJ, McAloon AJ, Yee WC, Foglia TA. A process model to estimate biodiesel production costs. Bioresource Technol. 2006;97:671-8.

[117] Apostolakou AA, Kookos IK, Marazioti C, Angelopoulos KC. Techno-economic analysis of a biodiesel production process from vegetable oils. Fuel Process Technol. 2009;90:1023-31.

[118] Jones SB, Zhu Y. Preliminary Economics for the Production of Pyrolysis Oil from Lignin in a Cellulosic Ethanol Biorefinery. Pacific Northwest National Laboratory; 2009.

[119] Hodges A, Rahmani M. Cost of Production of Camelina Oil in North Florida. University of Florida, IFAS; 2012.

[120] Richardson JW, Outlaw JL, Allison M. The Economics of Microalgae Oil. The Journal of Agrobiotechnology Management and Economics. 2010;13:119-30.

[121] Commerce F. Refining cooking oil into biofuel becomes a growing industry. 2012.

[122] Ash M. Oil Crops Outlook, Soybean Meal and Oil Prices Moderate Ahead of Declining Production. U. S. Department of Agriculture; 2013.

[123] Beijing Shennong Kexin Agribusiness Consulting Co. L. A Sharp Fluctuation in Domestic Rapeseed Oil Price in 2012. 2013.

[124] U.S. Energy Information Administration. Heating Oil and Propane Update. 2013.

[125] U.S. Energy Information Administration. Natural Gas Prices. 2013.

[126] Department of Energy. Biofuels Data. 2013.

[127] Bailis RE, Baka JE. Greenhouse Gas Emissions and Land Use Change from Jatropha CurcasBased Jet Fuel in Brazil. Environ Sci Technol. 2010;44:8684-91.

[128] Elgowainy A, Han J, Wang M, Carter N, Stratton R, Hilemaan J, et al. Life-Cycle Analysis of Alternative Aviation Fuels in Greet. Argonne National Laboratory; 2012.

[129] J. Hu FY, Y. Lu. Application of Fischer-Tropsch Synthesis in Biomass to Liquid Conversion. Catalysts. 2012;2:303-26.

[130] Dry ME. Practical and theoretical aspects of the catalytic Fischer-Tropsch process. Applied Catalysis A: General. 1996;138:319-44.

[131] Kreutz TG, Larson ED, Liu G, Williams RH. Fischer-Tropsch Fuels from Coal and Biomass. 25th Annual International Pittsburgh Coal Conference. Pittsburgh, Pennsylvania2008.

[132] You F, Wang B. Life Cycle Optimization of Biomass-to-Liquid Supply Chains with Distributed-Centralized Processing Networks. Industrial \& Engineering Chemistry Research. 2011;50:10102-27.

[133] Hamelinck CN, Faaij APC, den Uil H, Boerrigter H. Production of FT transportation fuels from biomass; technical options, process analysis and optimisation, and development potential. Energy. 2004;29:1743-71.

[134] Editorial. Present and future applications of the Fischer-Tropsch process. Applied Catalysis A: General. 2004;276:1-3.

[135] Sie ST, Krishna R. Fundamentals and selection of advanced Fischer-Tropsch reactors. Applied Catalysis A: General. 1999;186:55-70.

[136] MORALES F, WECKHUYSEN BM. Promotion Effects in Co-based Fischer-Tropsch Catalysis. Catalysis. 2006;19:1-40.

[137] Lualdi M, Lögdberg S, Regali F, Boutonnet M, Järås S. Investigation of Mixtures of a Co-Based Catalyst and a Cu-Based Catalyst for the Fischer-Tropsch Synthesis with Bio-Syngas: The Importance of Indigenous Water. Top Catal. 2011;54:977-85.

[138] Yan Z, Bukur DB, Goodman DW. Silica-supported rhodium-cobalt catalysts for FischerTropsch synthesis. Catalysis Today. 2011;160:39-43. 
[139] Khodakov AY. Fischer-Tropsch synthesis: Relations between structure of cobalt catalysts and their catalytic performance. Catalysis Today. 2009;144:251-7.

[140] den Breejen JP, Sietsma JRA, Friedrich H, Bitter JH, de Jong KP. Design of supported cobalt catalysts with maximum activity for the Fischer-Tropsch synthesis. Journal of Catalysis. 2010;270:14652.

[141] Davis BH. Fischer-Tropsch Synthesis: Reaction mechanisms for iron catalysts. Catalysis Today. 2009;141:25-33.

[142] den Breejen JP, Radstake PB, Bezemer GL, Bitter JH, Frøseth V, Holmen A, et al. On the Origin of the Cobalt Particle Size Effects in Fischer-Tropsch Catalysis. Journal of the American Chemical Society. 2009;131:7197-203.

[143] Dry ME. The Fischer-Tropsch process: 1950-2000. Catalysis Today. 2002;71:227-41.

[144] National Advanced Biofuels Consortium. Catalysis of Lignocellulosic Sugars Process Strategy. 2011.

[145] Daniell J, Köpke M, Simpson S. Commercial Biomass Syngas Fermentation. Energies. 2012;5:5372-417.

[146] Griffin DW, Schultz MA. Fuel and chemical products from biomass syngas: A comparison of gas fermentation to thermochemical conversion routes. Environmental Progress \& Sustainable Energy. 2012;31:219-24.

[147] Pray TR, Pramanik J, McPhee D, Galazzo J, Reiling K, Cherry J, et al. Amyris' integrated biorefinery operations for domestic renewable diesel and chemical production. 32nd Symposium on Biotechnology for Fuels and Chemicals. Clearwater Beach, FL2010.

[148] Advanced Biofuels USA. Syngas fermentation: The third pathway for cellulosic ethanol. 2011.

[149] Swanson RM, Satrio JA, Brown RC, Platon A, Hsu DD. Techno-Economic Analysis of Biofuels Production Based on Gasification. National Renewable Energy Laboratory: National Renewable Energy Laboratory; 2010.

[150] Anex RP, Aden A, Kazi FK, Fortman J, Swanson RM, Wright MM, et al. Techno-economic comparison of biomass-to-transportation fuels via pyrolysis, gasification, and biochemical pathways. Fuel. 2010;89, Supplement 1:S29-S35.

[151] Tijmensen MJA, Faaij APC, Hamelinck CN, van Hardeveld MRM. Exploration of the possibilities for production of Fischer Tropsch liquids and power via biomass gasification. Biomass and Bioenergy. 2002;23:129-52.

[152] Marano JJ, Ciferno JP. Life-Cycle Greenhouse-Gas Emissions Inventory For Fischer-Tropsch Fuels. National Energy Technology Laboratory; 2001.

[153] Xie X, Wang M, Han J. Assessment of Fuel-Cycle Energy Use and Greenhouse Gas Emissions for Fischer-Tropsch Diesel from Coal and Cellulosic Biomass. Environ Sci Technol. 2011;45:3047-53.

[154] Taylor CE, Baltrus JP, Driscoll D. Fischer-Tropsch Fuels. National Energy Technology Laboratory; 2011.

[155] Holmgren K, Hagberg L. LIfe cycle assessment of climate impact of Fischer-Tropsch diesel based on peat and biomass. Swedish Environmental Research Institute; 2009.

[156] Amyris. Amyris Enhances Strategic Partnership With Total for Renewable Diesel and Jet Fuels. 2012.

[157] USA AB. Combined Bacterial/Metal Catalysis Turns Sugars to Jet Fuel. 2012.

[158] Amyris. Azul Brazilian Airlines makes Successful Demonstration Flight with Amyris

Renewable Jet Fuel produced from Sugarcane. 2012.

[159] Virent Energy Systems Inc. Catalytic Conversion of Sugars to Conventional Liquid Fuels.

AIChE Annual Meeting. Nashville, TN2009.

[160] Gallezot P, Nicolaus N, Flèche G, Fuertes P, Perrard A. Glucose Hydrogenation on Ruthenium Catalysts in a Trickle-Bed Reactor. Journal of Catalysis. 1998;180:51-5.

[161] Vasilakos NP, Barreiros MT. Homogeneous catalytic hydrogenolysis of biomass. Industrial \& Engineering Chemistry Process Design and Development. 1984;23:755-63.

[162] Blommer PG, Cortright RD. Production of Conventional Liquid Fuels from Sugars. Virent Energy Systems, Inc.; 2008. 
[163] Held A. Catalytic Conversion of Renewable Plant Sugars to Fungible Liquid Hydrocarbon Fuels Using the BioForming Process. TAPPIO. Memphis, TN2009.

[164] Patrick W. Goguen TX, Dewey H. Barich, Timothy W. Skloss, Weiguo Song, Zhike Wang, John B. Nicholas, James F. Haw Pulse-Quench Catalytic Reactor Studies Reveal a Carbon-Pool Mechanism in Methanol-to-Gasoline Chemistry on Zeolite HZSM-5. J Am Chem Soc. 1998;120:2650-1.

[165] de Klerk A, Nel RJJ, Schwarzer R. Oxygenate Conversion over Solid Phosphoric Acid. Industrial \& Engineering Chemistry Research. 2007;46:2377-82.

[166] King F, Kelly GJ, Stitt EH. 98 Improved base catalysts for industrial condensation reactions. Studies in Surface Science and Catalysis. 2003;145:443-6.

[167] Gurbuz EI, Dumesic JA. Catalytic Strategies and Chemistries Involved in the Conversion of Sugars to Liquid Transportation Fuels. In: Behrens M, Datye AK, editors. Catalysis for the Conversion of Biomass and Its Derivatives. Berlin, Germany: Max Planck Research Library for the History and Development of Knowledge Proceedings 2; 2013.

[168] Gurbuz EI, Kunkes EL, Dumesic JA. Dual-bed catalyst system for C-C coupling of biomassderived oxygenated hydrocarbons to fuel-grade compounds. Green Chem. 2009;12:223-7.

[169] Roman-Leshkov Y, Barrett CJ, Liu ZY, Dumesic JA. Production of dimethylfuran for liquid fuels from biomass-derived carbohydrates. Nature. 2007;447:982-5.

[170] National Advanced Biofuels Consortium. Fermentation of Lignocellulosic Sugars Process Strategy. 2012.

[171] Schirmer A, Rude MA, Li X, Popova E, del Cardayre SB. Microbial Biosynthesis of Alkanes. Science. 2010;329:559-62.

[172] Lange BM, Rujan T, Martin W, Croteau R. Isoprenoid biosynthesis: The evolution of two ancient and distinct pathways across genomes. P Natl Acad Sci USA. 2000;97:13172-7.

[173] Steen EJ, Kang Y, Bokinsky G, Hu Z, Schirmer A, McClure A, et al. Microbial production of fatty-acid-derived fuels and chemicals from plant biomass. Nature. 2010;463:559-62.

[174] Kochergin V, Miller K. Evaluation of Target Efficiencies for Solid-Liquid Separation Steps in Biofuels Production. Applied Biochemistry and Biotechnology. 2011;163:90-101.

[175] Kazi FK, Patel AD, Serrano-Ruiz JC, Dumesic JA, Anex RP. Techno-economic analysis of dimethylfuran (DMF) and hydroxymethylfurfural (HMF) production from pure fructose in catalytic processes. Chemical Engineering Journal. 2011;169:329-38.

[176] Braden DJ, Henao CA, Heltzel J, Maravelias CC, Dumesic JA. Production of liquid hydrocarbon fuels by catalytic conversion of biomass-derived levulinic acid. Green Chemistry. 2011;13:1755-65.

[177] Cardona CA, Sanchez OJ. Fuel ethanol production: Process design trends and integration opportunities. Bioresource Technol. 2007;98:2415-57.

[178] OAK RIDGE NATIONAL LABORATORY. U.S. Billion-Ton Update: Biomass Supply for a Bioenergy and Bioproducts Industry. U.S. Department of Energy, Energy Efficiency and Renewable Energy, Office of the Biomass Program; 2011.

[179] Badr HR, Toledo R, Hamdy MK. Continuous acetone-ethanol-butanol fermentation by immobilized cells of Clostridium acetobutylicum. Biomass Bioenerg. 2001;20:119-32.

[180] Ezeji TC, Qureshi N, Blaschek HP. Production of acetone butanol (AB) from liquefied corn starch, a commercial substrate, using Clostridium beijerinckii coupled with product recovery by gas stripping. J Ind Microbiol Biotechnol. 2007;34:771-7.

[181] Foda MI DH, Li Y. Study the Suitability of Cheese Whey for Bio-Butanol Production by. Clostridia. J Am Sci. 2010;6:39-46.

[182] Qureshi N, Ezeji TC, Ebener J, Dien BS, Cotta MA, Blaschek HP. Butanol production by Clostridium beijerinckii. Part I: Use of acid and enzyme hydrolyzed corn fiber. Bioresource Technol. 2008;99:5915-22.

[183] Qureshi N, Saha BC, Dien B, Hector RE, Cotta MA. Production of butanol (a biofuel) from agricultural residues: Part I - Use of barley straw hydrolysate. Biomass Bioenerg. 2010;34:559-65.

[184] Qureshi N, Saha BC, Hector RE, Dien B, Hughes S, Liu S, et al. Production of butanol (a biofuel) from agricultural residues: Part II - Use of corn stover and switchgrass hydrolysates. Biomass Bioenerg. 2010;34:566-71. 
[185] Qureshi N, Sahaa BC, Hector RE, Hughes SR, Cotta MA. Butanol production from wheat straw by simultaneous saccharification and fermentation using Clostridium beijerinckii: Part I - Batch fermentation. Biomass Bioenerg. 2008;32:168-75.

[186] Hasegawa F, Yokoyama S, Imou K. Methanol or ethanol produced from woody biomass: Which is more advantageous? Bioresource Technol. 2010;101:S109-S11.

[187] Kumabe K, Fujimoto S, Yanagida T, Ogata M, Fukuda T, Yabe A, et al. Environmental and economic analysis of methanol production process via biomass gasification. Fuel. 2008;87:1422-7.

[188] Quann RJ, Green LA, Tabak SA, Krambeck FJ. Chemistry of olefin oligomerization over ZSM5 catalyst. Industrial \& Engineering Chemistry Research. 1988;27:565-70.

[189] Tabak SA, Yurchak S. Conversion of methanol over ZSM-5 to fuels and chemicals. Catalysis Today. 1990;6:307-27.

[190] Abhari R TL, Havlid P, Jannasch N. Hydrocracking Process for Biological Feedstocks and Hydrocarbons Produced Therefrom. US: Syntroleum Corporation; 2011. p. 1-13.

[191] Chempro. Fatty acid composition of oils and fats. 2012.

[192] Chhetri AB, Watts KC, Islam MR. Waste Cooking Oil as an Alternate Feedstock for Biodiesel Production. Energies. 2008;1:3-18.

[193] D'oca MGM, Morón-Villarreyes JA, Lemões JS, Costa CSB. Fatty acids composition in seeds of the South American glasswort Sarcocornia ambigua. Anais da Academia Brasileira de Ciências.

2012;84:865-70.

[194] O'Brien RD. Fats and Oils: Formulating and Processing for Applications. Boca Raton, FL: CRC Press; 2009.

[195] Oregon State University. Camelina. Oregon State University2008.

[196] Sheehan J, Camobreco V, Duffield J, Graboski M, Shapouri H. Life cycle inventory of biodiesel and petroleum diesel for use in an urban bus. Final report. Other Information: Supercedes report DE98005500; PBD: May 1998; PBD: 1 May 1998: National Renewable Energy Laboratory; 1998. p. Medium: ED; Size: 315 pages.

[197] Sigma-Aldrich. Fatty Acid/FAME Application Guide. Sigma-Aldrich2008.

[198] Silva RVS, Romeiro GA, Veloso MCC, Figueiredo MKK, Pinto PA, Ferreira AF, et al. Fractions composition study of the pyrolysis oil obtained from sewage sludge treatment plant. Bioresource Technol. 2012;103:459-65.

[199] Agusdinata DB, Zhao F, DeLaurentis DA. Sustainability of Biojet Fuels: A Multiactor Life Cycle Assessment Approach Potentials, IEEE. 2012;31:27-33.

[200] Sharma V, Das L, Pradhan RC, Naik SN, Bhatnagar N, Kureel RS. Physical properties of tung seed: An industrial oil yielding crop. Industrial Crops and Products. 2011;33:440-4.

[201] Wright MM, Satrio JA, Brown RC, Daugaard DE, Hsu DD. Techno-Economic Analysis of Biomass Fast Pyrolysis to Transportation Fuels. National Renewable Energy Laboratory; 2010.

[202] Miao X, Wu Q, Yang C. Fast pyrolysis of microalgae to produce renewable fuels. Journal of Analytical and Applied Pyrolysis. 2004;71:855-63.

[203] Elliott D. Biomass Pyrolysis to Liquid Fuels in the U.S. In: Laboratory PNN, editor. 2G 2020 Biofuels Seminar. Helsinki, Finland2012.

[204] Olarte MB Valenzuela ZA, Elliott DC, Santosa DM, Neuenschwander, Hart TR, Rotness LJ. Bio-Upgrading and Stabilization at PNNL. In: Laboratory PNN, editor. Harvesting Clean Energy Conference 2011. Boise, Idaho2011.

[205] Oasmaa A, Kuoppala E, Gust S, Solantausta Y. Fast Pyrolysis of Forestry Residue. 1. Effect of Extractives on Phase Separation of Pyrolysis Liquids. Energ Fuel. 2002;17:1-12.

[206] Miao X, Wu Q. High yield bio-oil production from fast pyrolysis by metabolic controlling of Chlorella protothecoides. Journal of Biotechnology. 2004;110:85-93.

[207] Tsai WT, Lee MK, Chang YM. Fast pyrolysis of rice straw, sugarcane bagasse and coconut shell in an induction-heating reactor. Journal of Analytical and Applied Pyrolysis. 2006;76:230-7.

[208] Boateng AA, Daugaard DE, Goldberg NM, Hicks KB. Bench-Scale Fluidized-Bed Pyrolysis of Switchgrass for Bio-Oil Production $\uparrow$. Industrial \& Engineering Chemistry Research. 2007;46:1891-7. 
[209] Jones S, Holladay J, Valkenburg C, Stevens D, Walton C, Kinchin C, et al. Production of Gasoline and Diesel from Biomass via Fast Pyrolysis, Hydrotreating and Hydrocracking: A Design Case. Pacific Northwest National Laboratory; 2009.

[210] Baliban RC, Elia JA, Floudas CA. Toward Novel Hybrid Biomass, Coal, and Natural Gas Processes for Satisfying Current Transportation Fuel Demands, 1: Process Alternatives, Gasification Modeling, Process Simulation, and Economic Analysis. Industrial \& Engineering Chemistry Research. 2010;49:7343-70.

[211] Economides MJ. The Economics of Gas to Liquids Compared to Liquefied Natural Gas. World Energy Magazine2005. p. 136-40. 94.

[212] Milici R. Coal-to-Liquids: Potential Impact on U.S. Coal Reserves. Nat Resour Res. 2009;18:85-

[213] US DOE/Energy Inforamtion Administration. US coal Reserves. US Department of Energy; 2013.

[214] Mantripragada HC, Rubin ES. Techno-economic evaluation of coal-to-liquids (CTL) plants with carbon capture and sequestration. Energy Policy. 2011;39:2808-16.

[215] Baliban RC, Elia JA, Floudas CA, Gurau B, Weingarten MB, Klotz SD. Hardwood Biomass to Gasoline, Diesel, and Jet Fuel: 1. Process Synthesis and Global Optimization of a Thermochemical Refinery. Energ Fuel. 2013.

[216] Phillips SD, Tarud JK, Biddy MJ, Dutta A. Gasoline from Wood via Integrated Gasification, Synthesis, and Methanol-to-Gasoline Technologies. 2011. p. Medium: ED; Size: 115 pp.

[217] Speight JG. Natural Gas - A Basic Handbook. Gulf Publishing Company.

[218] Datta R, Corley R. Intergrated Process for Production of Alochol from Syngas and Removal of CO2. United States2011. p. 11.

[219] Gaiaquinta R. Sucrose Translocation and Storage in the Sugar Beet. Plant Physiology 1979;63:4.

[220] Lloyd TA, Wyman CE. Combined sugar yields for dilute sulfuric acid pretreatment of corn stover followed by enzymatic hydrolysis of the remaining solids. Bioresource Technol. 2005;96:1967-77.

[221] Muchow RC, Robertson MJ, Wood AW. Growth of sugarcane under high input conditions in tropical Australia. II. Sucrose accumulation and commercial yield. Field Crops Research. 1996;48:27-36.

[222] Shi J, Ebrik MA, Wyman CE. Sugar yields from dilute sulfuric acid and sulfur dioxide pretreatments and subsequent enzymatic hydrolysis of switchgrass. Bioresource Technol. 2011;102:89308.

[223] Atsumi S, Hanai T, Liao JC. Non-fermentative pathways for synthesis of branched-chain higher alcohols as biofuels. Nature. 2008;451:86-U13.

[224] Argonne National Laboratory. GREET, The Greenhouse Gases, Regulated Emissions, and Energy Use In Transportation Model. GREET 1.8d.1 ed2011.

[225] Mehta PS, Anand K. Estimation of a Lower Heating Value of Vegetable Oil and Biodiesel Fuel. Energ Fuel. 2009;23:3893-8.

[226] World J. JATROPHA BIODIESEL MAKING. 2013.

[227] Bernardo A, Howard-Hildige R, O'Connell A, Nichol R, Ryan J, Rice B, et al. Camelina oil as a fuel for diesel transport engines. Industrial Crops and Products. 2003;17:191-7.

[228] Frank ED, Han J, Palou-Rivera I, Elgowainy A, Wang MQ. User Manual for Algae Life-Cycle Analysis with GREET: Version 0.0. Argonne National LAboratory; 2011.

[229] Hartmann RM, Garzón NN, Hartmann EM, Oliveira AAM, Bazzo E. Vegetable Oils of Soybean, Sunflower and Tung as Alternative Fuels for Compression Ignition Engines. International Journal of Thermodynamics. 2013;16:87-96.

[230] Ringer M, Putsche V, Scahill J. Large-Scale Pyrolysis Oil Production: A Technology November 2006 Assessment and Economic Analysis. National Renewable Energy Laboratory; 2006.

[231] Stuve EM. Energy - What are the Technical, Economic, and Political Implications of Meeting our Basic Energy Needs?

[232] Curt MD, Fernandez J, Martinez M. Productivity and radiation use efficiency of sweet sorghum (Sorghum bicolor (L.) Moench) cv. Keller in central Spain. Biomass and Bioenergy. 1998;14:169-78. 
[233] Tarud J, Phillips S. Technoeconomic Comparison of Biofuels: Ethanol, Methanol, and Gasoline from Gasification of Woody Residues 2011 ACS National Meeting and Exposition. Denver, Colorado2011.

[234] Davis R, Aden A, Pienkos PT. Techno-economic analysis of autotrophic microalgae for fuel production. Applied Energy. 2011;88:3524-31.

[235] Renewable Energy World.com. Everyday Low (Fuel) Prices: Drop-in Advanced Biofuels for Under \$100 per Barrel 2012.

[236] Badger P, Badger S, Puettmann M, Steele P, Cooper J. TECHNO-ECONOMIC ANALYSIS: PRELIMINARY ASSESSMENT OF PYROLYSIS OIL PRODUCTION COSTS AND MATERIAL ENERGY BALANCE ASSOCIATED WITH A TRANSPORTABLE FAST PYROLYSIS SYSTEM. BioResouces. 2011;6:34-47.

[237] Talmadge M. Techno-economic analysis for the conversion of biomass-derived syngas to fuels and chemicals. National Renewable Energy Laboratory; 2012.

[238] Piccolo C, Bezzo F. A techno-economic comparison between two technologies for bioethanol production from lignocellulose. Biomass and Bioenergy. 2009;33:478-91.

[239] Davis R, Biddy M, Tan E, Tao L, Jones S. Biological Conversion of Sugars to Hydrocarbons Technology Pathway. National Renewable Energy Laboratory/Pacific Northwest National Laboratory; 2013.

[240] SRI Consulting. U.S. Producer Price Indexes - Chemicals and Allied Products/Industrial Inorganic Chemicals Index. Chemical Economics Handbook2008.

[241] Carter NA, Stratton RW, Bredehoeft MK, Hileman JI. Energy and Environmental Viability of Select Alternative Jet Fuel Pathways. 47th AIAA/ASME/SAE/ASEE Joint Propulsion Conference \& Exhibit. San Diego, California2011.

[242] Han J, Elgowainy A, Cai H, Wang MQ. Life-cycle analysis of bio-based aviation fuels. Bioresource Technol.

[243] Carter NA. Environmental and Economic Assessment of Microalgae-derived Jet Fuel: Massachusetts Institute of Technology; 2010. 